\title{
Marine Shell Working at Harlaa, Ethiopia, and the Implications for Red Sea Trade
}

\author{
Timothy Insoll | ORCID: 0000-0002-3072-3088 \\ Institute of Arab and Islamic Studies, University of Exeter, Stocker Road, EX4 4ND Exeter, UK \\ T.Insoll@Exeter.ac.uk
}

\begin{abstract}
Twelve species of marine shell were transported in significant quantities from the Red Sea to the trade centre of Harlaa in eastern Ethiopia between the eleventh and early fifteenth centuries AD. Initially, it was thought that species such as the cowries were imported from the Indian Ocean. Subsequent research has found that all were available from the Red Sea and the Gulf of Aden, c. $120 \mathrm{~km}$ east of Harlaa. This suggests that a hitherto largely unrecognised source of marine shells was available, and the Red Sea might have supplied not only the Horn of Africa, but other markets, potentially including Egypt, and from there, elsewhere in North Africa and ultimately West Africa via transSaharan routes, as well as Nubia and further south on the Nile in the Sudan, the Arabian Peninsula, and the Arabian/Persian Gulf. This is explored with reference to the shell assemblage from Harlaa, and selected shell assemblages from elsewhere in the Horn of Africa, and trading centres on the Red Sea.
\end{abstract}

\section{Keywords}

shell - archaeomalacology - Harlaa - Red Sea - trade Ethiopia - Islamic archaeology

\section{Introduction}

Significant quantities of marine shell were transported from the Red Sea to the trade centre of Harlaa in eastern Ethiopia between the eleventh and early fifteenth centuries (all dates are AD unless otherwise specified). Only twelve species were represented (described below), which appear not to have been food items, but were imported to be processed in Harlaa as trade goods, for use in other contexts for adornment and decoration, and possibly ritual, divination, and currency, as recorded elsewhere in sub-Saharan Africa (e.g. Hogendorn \& Johnson 1986; Ogundiran 2002; Patscher 2011; Magnavita 2015; Moffett \& Hall 2019). The initial hypothesis was that species such as the cowries were imported from the Indian Ocean: Monetaria moneta (formerly Cypraea moneta) possibly from well-known sources such as the Maldive Islands (e.g. Hogendorn \& Johnson 1986) and Monetaria annulus (formerly Cypraea annulus) from the East African coast (e.g. Christie et al. 2019: 499). Subsequent indications are that these cowries, and the other ten species found were all available from the Red Sea and the Gulf of Aden, c. $120 \mathrm{~km}$ east of Harlaa. This suggests that a hitherto largely unrecognised source of marine shells was available, and the Red Sea might have supplied not only the Horn of Africa, but other markets, potentially including Egypt, and from there, elsewhere in North Africa and ultimately West Africa via trans-Saharan routes, as well as Nubia and further south on the Nile in the Sudan, the Arabian Peninsula, and the Arabian/Persian Gulf. This idea is examined with reference to the marine shells from Harlaa, and selected shell assemblages from elsewhere in the Horn of Africa, and trading centres on the Red Sea.

\section{$2 \quad$ Harlaa}

Harlaa $\left(9^{\circ} 29^{\prime} 10.22^{\prime \prime} \mathrm{N}, 41^{\circ} 54^{\prime} 36.96^{\prime \prime} \mathrm{E}\right)$ is located at 1700 $\mathrm{m}$ ASL on the edge of the main fault escarpment of the southern Afar margin underneath the modern Oromo village of Ganda Biyo, approximately $40 \mathrm{~km}$ northwest of Harar and $15 \mathrm{~km}$ southeast of Dire Dawa (Khalaf \& Insoll 2019) (Fig. 1). Since 2015, six field seasons have been completed at Harlaa, as part of the Becoming Muslim project (ERC-2015-AdG BM694254). Several areas have been excavated including a mosque (A), a workshop complex (B), cemeteries (C and D), a house with associated industrial/kitchen facility (E), an extensive building complex, probably with a civic function $(\mathrm{F})$, and a cluster of stone 


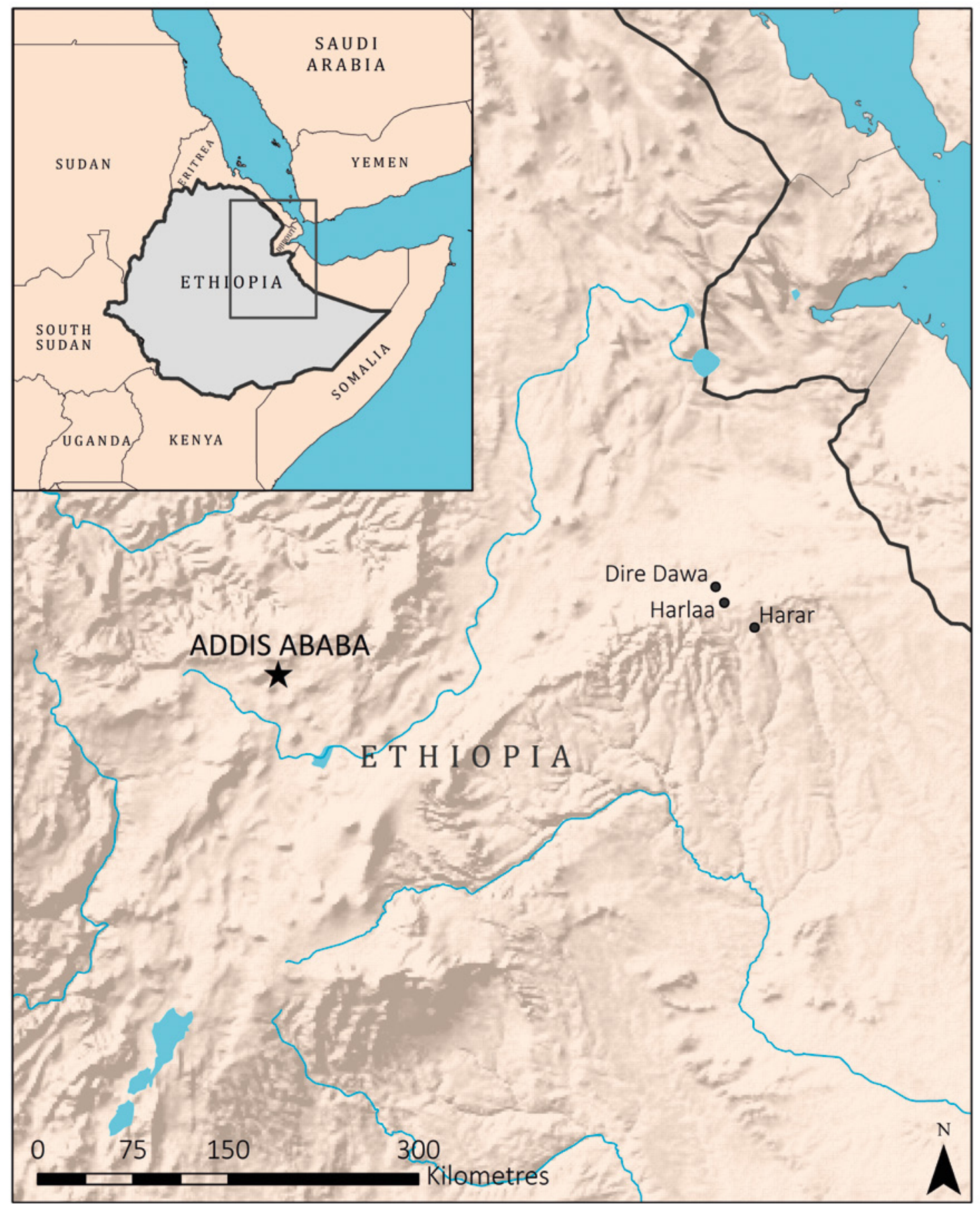

FIGURE 1 The location of Harlaa within Ethiopia PREPARED BY N. KHALAF

houses (G) (Fig. 2) (Insoll et al. 2016, 2017, in press; Khalaf \& Insoll 2019; Gaastra \& Insoll 2020; Pryor, Insoll, and Evis 2020; Insoll forthcoming). Twenty-seven AMs dates have been obtained, indicating occupation between the mid-sixth and fifteenth centuries (Table 1). Harlaa was a large urban centre, partly walled, with cemeteries on three sides, to the north, east, and west (Khalaf \& Insoll 2019). The topographic position of Harlaa suggests that it can be identified with Hubät/Hobat, the capital of the Hārlā sultanate (Insoll et al. in press), for the Somali word hoobat and the Arabic hubuut both mean to descend a slope from an upland point, and suggest the mid-point between the highland and the lowland (S. Hussein, pers. comm. 11/3/20), precisely where Harlaa is. The Hārlā sultanate was a territory affiliated to the much larger Islamic polity of Ifat (c. 1286-1435/36) (Stenhouse 2003: 69). 




FIGURE 2 Plan of Harlaa with excavated areas indicated PREPARED BY N. KHALAF 


\begin{tabular}{|c|c|c|}
\hline Context Number & Laboratory Number & Date (2 sigma calibration) \\
\hline HAR $15($ A) 10 & Beta-419525 & 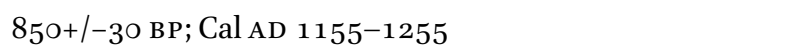 \\
\hline HAR 15 (B) 6 & Beta-419526a & $840+/-3$ в \\
\hline HAR 15 (B) 10 & Beta-41952 $7^{\mathrm{a}}$ & $82 \mathrm{O}+/-3 \mathrm{O} \mathrm{BP} ;$ Cal AD $1165^{-1265}$ \\
\hline HAR $16(\mathrm{~B}) 6$ & Beta- $4515^{81^{a}}$ & $610+/-30 \mathrm{BP} ; \mathrm{Cal}$ AD 1290 to 1410 \\
\hline HAR $16(B) 7$ & Beta- $451582^{a}$ & $73 \mathrm{O}+/-3$ о вР; Cal AD 1255 to 1290 \\
\hline HAR $16(\mathrm{~B}) 9$ & Beta- $45^{1} 5^{8} 3^{\mathrm{a}}$ & $800+/-3$ о вР; Cal AD 119 o to 1275 \\
\hline HAR 17 (B) 6 - Hearth & Beta-461299 & $760+/-3$ о вр; Cal AD 1220 to 1285 \\
\hline HAR 17 (B) 10 & Beta- $461300^{a}$ & $900+/-30 \mathrm{BP} ; \mathrm{Cal}$ AD 1035 to 1215 \\
\hline HAR 17 (B) 15 & Beta- $461301^{a}$ & $1500+/-30 \mathrm{BP} ; \mathrm{Cal}$ AD 535 to 620 \\
\hline HAR 17 (B) $24-$ Hearth & Beta- $461302^{a}$ & 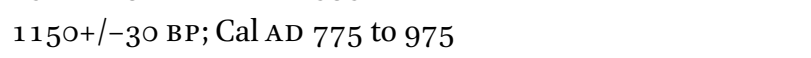 \\
\hline HAR 17 (B) 24 - Under Wall & Beta- $461303^{a}$ & $98 \mathrm{O}+/-3 \mathrm{O}$ BP; Cal AD 1015 to $105^{\circ}$ and Cal AD 108 o to $115^{\circ}$ \\
\hline HAR 18 (B) 6 & Beta- $490904^{\mathrm{a}}$ & $710+/-3$ о вр; Cal AD 1256 to 1306 \\
\hline HAR $18(B) 13$ & Beta-49090 $5^{\mathrm{a}}$ & $85^{\mathrm{O}}+/-3$ о вр; Cal AD $115^{2}$ to 126 о \\
\hline HAR 18 (B) 24 & Beta-49o9o6 ${ }^{a}$ & $115^{\mathrm{O}+/-30}$ вР; Cal AD 776 to 971 \\
\hline HAR 18 (B) 26 & Beta- $490907^{\mathrm{a}}$ & $1240+/-30$ BP; Cal AD 684 to 78 o \\
\hline HAR 17 (C) Burial 1 - Upper & Beta-461292 & $520+/-3$ о вP; Cal AD 1330 to 1340 and Cal AD 1395 to 1440 \\
\hline HAR 17 (C) Burial 2 - Lower & Beta- $461293^{b}$ & $76 \mathrm{o}+/-3 \mathrm{O} \mathrm{BP} ;$ Cal AD 1220 to 1285 \\
\hline HAR $17(\mathrm{D}) 1$ & Beta- $461294^{b}$ & $82 \mathrm{O}+/-3$ о вР; Cal AD 1165 to 1265 \\
\hline HAR $18(\mathrm{E}) 8$ & Beta-49o9o8a & $900+/-30 \mathrm{BP} ; \mathrm{Cal} \mathrm{AD} 1039$ to 1210 \\
\hline HAR $18(\mathrm{E}) 9$ & Beta-49o9o9a & $840+/-3$ о вР; Cal AD 1154 to 1264 \\
\hline HAR 19 (E) 30 & Beta- $522144^{\mathrm{a}}$ & $92 \mathrm{O}+/-3 \mathrm{O} \mathrm{BP} ; \mathrm{Cal}$ AD 1028 to 1184 \\
\hline HAR $19(\mathrm{~F}) 6$ & Beta- $522142^{a}$ & $810+/-3$ о Ве; Cal AD 1169 to 1270 \\
\hline HAR $19(\mathrm{~F})-($ Cut Section $)$ & Beta- $522143^{a}$ & $82 \mathrm{O}+/-3$ о вP; Cal AD 1165 to 1265 \\
\hline \multicolumn{3}{|l|}{ Below Plaster Floor (2) } \\
\hline Harlaa Valley Section $1-10 \mathrm{~cm}$ & Beta- $461295^{\mathrm{a}}$ & $98 \mathrm{O}+/-3 \mathrm{O} \mathrm{BP} ; \mathrm{Cal} \mathrm{AD} 1015$ to $105^{\circ}$ and Cal AD 108 o to $115^{\circ}$ \\
\hline Harlaa Valley Section $1-110 \mathrm{~cm}$ & Beta- $461296^{a}$ & $1120+/-3$ о BP; Cal AD 78 o to 785 and Cal AD 88 o to $99 \circ$ \\
\hline Harlaa Valley Section $2-20 \mathrm{~cm}$ & Beta- $461297^{a}$ & $82 \mathrm{O}+/-3 \mathrm{O} \mathrm{BP} ; \mathrm{Cal}$ AD 1165 to 1265 \\
\hline Harlaa Valley Section $2-90 \mathrm{~cm}$ & Beta-461298 & $900+/-30 \mathrm{BP} ; \mathrm{Cal} A D 1035$ to 1215 \\
\hline
\end{tabular}

a Dates from charcoal.

b Dates from bone collagen. Calibration by BetaCal 3.21. HPD method: INTCAL13

The existence of a Muslim community at Harlaa is attested by $\mathrm{C}_{14}$ dates from burials and a mosque, and by Arabic inscriptions, by the mid-twelfth century (Insoll et al. in press). The period between the eleventh and thirteenth centuries appears to have been a particular highpoint in trade and manufacturing at Harlaa, correlating with the flourishing of Red Sea trade networks after they had been re-opened by the Fatimids who gained power in Egypt in 969 (Tamrat 1972: 44; Insoll forthcoming). Contacts, direct and indirect, with the Red Sea, western Indian Ocean, China, South and Central Asia, Egypt, the Ethiopian Interior, East African coast, and Arabian/Persian Gulf are indicated by material found. Imported ceramics included black-on-yellow and other glazed wares of Yemeni/southern Red Sea provenance, Iranian lustre glazed frit (Insoll et al. in press), Chinese celadon and white wares, and Martaban jar fragments of Chinese and Southeast Asian/ Chinese origin (Parsons-Morgan forthcoming). LA-ICP-MS analysis of four glass beads and five glass vessel fragments suggested Central Asian (vessels and beads), Middle Eastern (beads) and Sri Lankan/South Asian (beads) provenance (Dussubieux 2018). Similar analysis of four agate bead samples indicated Gujarati, Iranian, and an unknown source (Dussubieux 2018), possibly Ethiopia. Talc schist and chlorite schist were used to produce cooking vessels, and were, respectively, possibly from the 
Arabian Peninsula (V. Serneels, pers. comm. 23/10/18) and Madagascar. Pure quartz (rock crystal) working debris was also identified (Spence forthcoming), and is likely also of Madagascan origin (e.g. Horton et al. 2017).

\section{Shell Working at Harlaa}

\subsection{The Shell Assemblage}

The shell assemblage discussed was recovered from sites HAR-A, HAR-B, HAR-C, HAR-E, and HAR-F, and was composed of 2385 worked and unworked marine shells and shell fragments, and six shell beads (Tables 2 and 3 ). No freshwater shell was identified. Additionally, 76 marine shells and two shell beads were collected from HAR-G. Except for the shell beads and a single worked shell these are not included here, as the focus of this excavation was on exploring architecture on a large scale and, unlike the other units, the deposits were not sieved and are therefore notdirectly comparable. Species identifications were made using the comparative collections at the Natural History
Museum, London, and Sharabati (1984), Burgess (1970), and Bosch et al. (1995). All shells were examined individually and twelve species were identified, Monetaria annulus (Linnaeus 1758), Monetaria moneta (Linnaeus 1758), Cypraea erythraeensis (G.B. Sowerby I, 1837) Strombus tricornis (Lightfoot 1786), Oliva bulbosa (Röding 1798), Oliva ancillarioides (Reeve 1850), Marginella monilis (Linnaeus 1758), Anadara antiquata (Linnaeus 1758), Engina mendicaria (Linnaeus 1758), Conus erythraeensis (Reeve 1843), Conus nussatella (Linnaeus 1758), Pteriidae sp. (Gray 1847 [1820]) (Fig. 3). Where a species was unclear, they were classified as unidentified. An exception was made for the category Cypraea which was used where the type of cowry could not be differentiated based on the criteria defined by Christie et al. (2019:484-488) such as shape and number of teeth, tubercules around the dorsum, callus, size, and profile (Table 2). Although described as Cypraea, it is probable that the majority, if not all of the cowries in this category, are either M. annulus or M. moneta as only one example of another cowry species was identified, Cypraea erythraeensis.

TABLE 2 The marine shell species from the Harlaa sites (the six beads are included in the unidentified category)

\begin{tabular}{|c|c|c|c|c|c|c|}
\hline Shell Species & $\begin{array}{l}\text { HAR-A (mid- } \\
\text { 12th to mid- } \\
\text { 13th century) }\end{array}$ & $\begin{array}{l}\text { HAR-B (mid- } \\
6 \text { th to early } \\
\text { 15th century) }\end{array}$ & $\begin{array}{l}\text { HAR-C (mid- } \\
\text { 13th to mid- } \\
\text { 15th century) }\end{array}$ & $\begin{array}{l}\text { HAR-E (mid- } \\
\text { 11th to mid- } \\
\text { 13th century) }\end{array}$ & $\begin{array}{l}\text { HAR-F (mid- } \\
\text { 12th to mid- } \\
\text { 13th century) }\end{array}$ & Total \\
\hline Unidentified & & 61 & & 25 & 5 & 91 \\
\hline Cypraea-dorsa & & 1082 & & 269 & 1 & $135^{2}$ \\
\hline Cypraea-dorsal ring & & 4 & & & 1 & 5 \\
\hline Cypraea & & 255 & 1 & 30 & 4 & 290 \\
\hline Monetaria annulus & 2 & 74 & & 12 & 2 & 90 \\
\hline Monetaria moneta & & 29 & & 5 & & 34 \\
\hline Cypraea erythraeensis & & 1 & & & & 1 \\
\hline Strombus tricornis & & 138 & & 165 & 74 & 377 \\
\hline Oliva bulbosa & & 53 & 1 & 12 & 8 & 74 \\
\hline Oliva ancillarioides & & 7 & & 4 & & 11 \\
\hline Marginella monilis & & 26 & & 7 & & 33 \\
\hline Anadara antiquata & & 2 & & 1 & & 3 \\
\hline Engina mendicaria & & 1 & & 1 & & 2 \\
\hline Conus erythraeensis & & 4 & & 1 & 1 & 6 \\
\hline Conus nussatella & & & & & 2 & 2 \\
\hline Pteriidae sp. & & 11 & & 3 & & 14 \\
\hline Total & 2 & 1748 & 2 & 535 & 98 & 2385 \\
\hline
\end{tabular}


TABLE 3 Identifiable complete shells, modified shells, shell objects, and fragments from Harlaa

\begin{tabular}{|c|c|c|c|c|c|c|}
\hline Shape & HAR-A & HAR-B & HAR-C & HAR-E & HAR-F & Total \\
\hline Short barrel bead & & 1 & & & & 1 \\
\hline Long barrel bead & & 1 & & & & 1 \\
\hline Long bicone bead & & & & 2 & & 2 \\
\hline Dome bead & & 1 & & & & 1 \\
\hline Facetted ellipsoid bead & & 1 & & & & 1 \\
\hline Cypraea-dorsa & & 1082 & & 269 & 1 & $135^{2}$ \\
\hline Cypraea - dorsal ring & & 4 & & & 1 & 5 \\
\hline Cypraea-complete & & & & 1 & & 1 \\
\hline Cypraea - dorsa removed & & 19 & & 13 & 1 & 33 \\
\hline Cypraea - half & & 229 & 1 & 15 & 2 & 247 \\
\hline Cypraea-quarter & & 6 & & 1 & 1 & 8 \\
\hline Cypraea - fragment & & 1 & & & & 1 \\
\hline M. annulus - complete & 1 & 24 & & 3 & & 28 \\
\hline M. annulus - dorsa removed & 1 & 46 & & 9 & 2 & $5^{8}$ \\
\hline M. annulus - hole in dorsum & & 1 & & & & 1 \\
\hline M. annulus - half & & 3 & & & & 3 \\
\hline M. moneta-complete & & 7 & & 1 & & 8 \\
\hline M. moneta-dorsa removed & & 12 & & 3 & & 15 \\
\hline M. moneta - half & & 10 & & 1 & & 11 \\
\hline C. erythraeensis - complete & & 1 & & & & 1 \\
\hline Strombus tricornis - fragments & & 138 & & 165 & 74 & 377 \\
\hline Oliva bulbosa - complete & & 18 & 1 & 3 & & 22 \\
\hline Oliva bulbosa - modified (apex removed and/or cut) & & 5 & & 4 & 6 & 15 \\
\hline Oliva bulbosa - half & & 1 & & & & 1 \\
\hline Oliva bulbosa - fragments & & 29 & & 5 & 2 & 36 \\
\hline Oliva ancillarioides - complete & & 1 & & 2 & & 3 \\
\hline Oliva ancillarioides - modified (apex removed and/or cut) & & 4 & & 2 & & 6 \\
\hline Oliva ancillarioides - fragment & & 2 & & & & 2 \\
\hline Marginella monilis - complete & & 25 & & 7 & & 32 \\
\hline Marginella monilis - modified (dorsa removed) & & 1 & & & & 1 \\
\hline Anadara antiquata - fragments & & 2 & & 1 & & 3 \\
\hline Engina mendicaria - modified (hole in dorsum) & & 1 & & 1 & & 2 \\
\hline Conus erythraeensis - complete & & 2 & & 1 & & 3 \\
\hline Conus erythraeensis - modified & & & & & 1 & 1 \\
\hline Conus erythraeenis - fragments & & 2 & & & & 2 \\
\hline Conus nussatella - fragments & & & & & 2 & 2 \\
\hline Pteriidae sp. - fragments & & 11 & & 3 & & 14 \\
\hline Total & 2 & 1691 & 2 & $5^{12}$ & 93 & 2300 \\
\hline
\end{tabular}

The excavated marine shell assemblage was dominated by Cypraea (1772 or $74.30 \%)$, followed by Strombus (377 or $15.81 \%)$, and Oliva (85 or $3.56 \%)$. Infrequent species were Marginella monilis (33 or $1.38 \%$ ), and Pteriidae (14 or $0.59 \%)$. Rarer species with less than ten examples (whole or fragmentary) found were Conus erythraeensis (6 or $0.25 \%)$, Anadara antiquata (3 or $0.13 \%$ ), and Engina mendicaria and Conus nussatella (2 or $0.08 \%$ each) (Table 2). All the identified species could have been imported from the Red Sea/Gulf of Aden where they are indigenous (A. Salvador, pers. comm. 9/4/19; Sharabati 1984). Most species appear to have been obtained from the intertidal zone or seashore (e.g. Cypraea, Oliva), from shallow water (e.g. Conus, Marginella, Anadara), and inner 

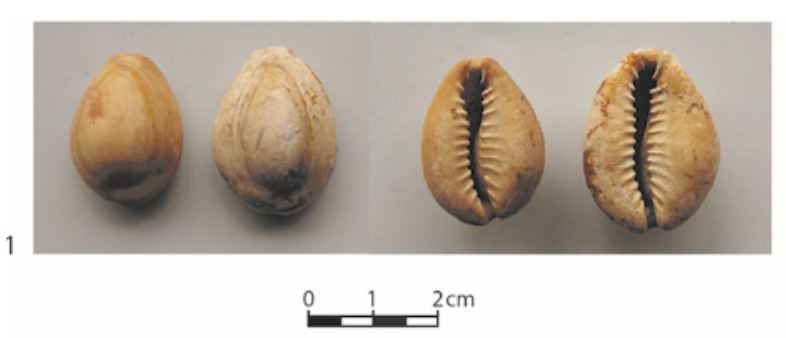

2

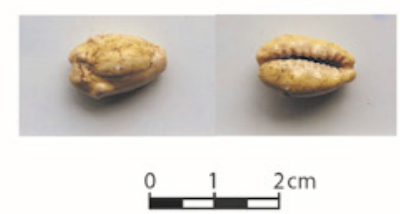

5

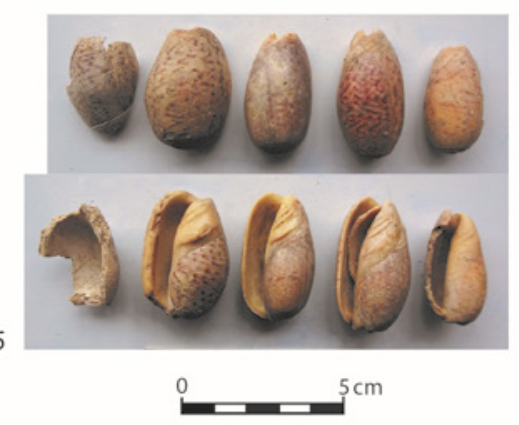

7

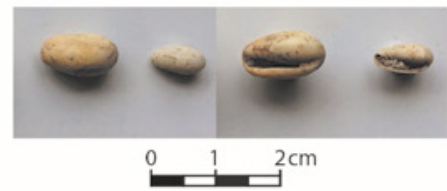

8
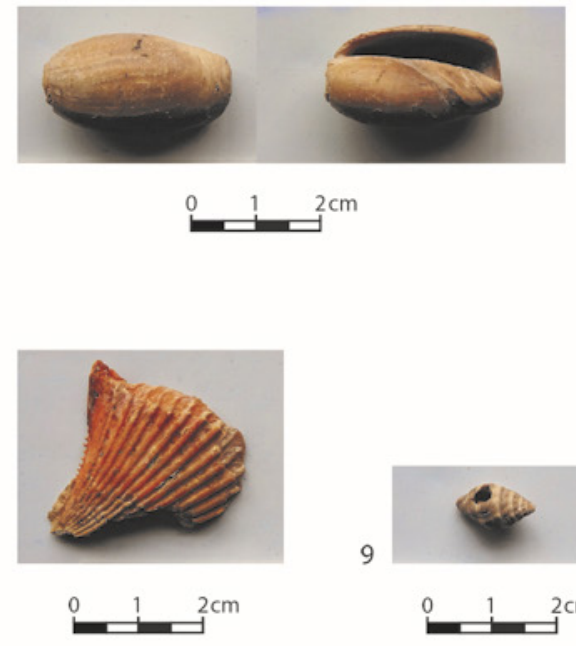

9

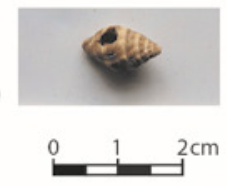

11



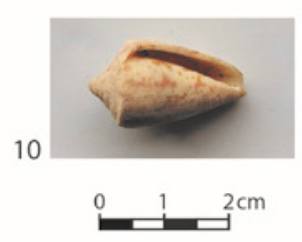

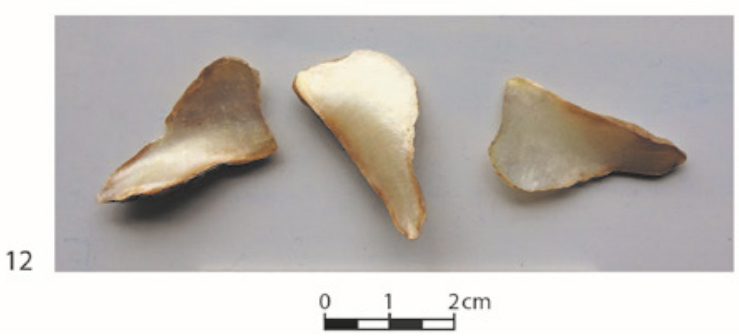

\section{FIGURE 3}

The marine shell species from Harlaa. (1) Monetaria annulus (HAR18-B-14).

(2) Monetaria moneta (HAR18-B-11). (3) Cypraea erythraeensis (HAR18-B-10).

(4) Strombus tricornis (HAR16-B-11). (5) Oliva bulbosa (HAR16-B-7).

(6) Oliva ancillarioides

(HAR19-E-14).

(7) Marginella monilis (HAR16-A-4). (8) Anadara antiquata (HAR17-B-11).

(9) Engina mendicaria (HAR18-B-8). (10) Conus erythraeensis (HAR16-B-8).

(11) Conus nussatella (HAR19-F-6). (12) Pteriidae sp. (HAR15-B-6)

PHOTOS BY THE AUTHOR reef or tidal flats (e.g. Engina, Strombus) (Sharabati 1981: 67-68, 73, 75, 93, 1984: Plates 9, 11, 24, 38). The exception was the Pteriidae (oysters), which are found on the lower shore or offshore (Bosch et al. 1995: 219-220). The very low frequency of the only species known to be used as food, Anadara antiquata (three fragments) and Pteriidae sp. (14 fragments) strongly suggests that they were not imported as a dietary resource.
The vast majority of the assemblage was composed of fragments of shells, part shells, or modified shells, with complete unmodified specimens less common (Table 3). Of the identified $M$. annulus, 28 were complete, whereas 58 had their dorsa (back) removed, and eight of the identified M. moneta were complete, and 15 had their dorsa removed. Much greater disparity was evident in the Cypraea category with one complete shell recorded, and 
33 with the dorsa removed. $O$. bulbosa had a slightly higher prevalence of complete shells, 22, compared to 15 that had been modified. In contrast, Marginella monolis was represented by 32 complete shells and one modified example (Table 3). Based on these patterns, it would appear that surviving complete Cypraea and O. bulbosa shells represent raw material rather than items that would have been traded in their own right.

Several types of modification recurred in the shell assemblage (Table 3). Dorsa removal was most frequent with cowries commonly modified in this way, and represented by the dorsa themselves ( $135^{2}$ examples; Fig. 4.1) or by shells with the dorsa removed (106 examples; Fig. 4.2). The recovery of such a large number of cowry shell dorsa appears to be unique, with no comparable examples found in, for example, the archaeological literature from Africa, the Indian Ocean, or the Arabian
Peninsula. A single Marginella also had its dorsa removed (Fig. 4.3). Cowries were also frequently cut or broken in half, along the length of the shell (26o examples; Fig. 4.4), and, in a single example, across the shell (Fig. 4.5). Other rarer cowry modifications were cutting into quarters (eight examples; not illustrated), and cutting off the dorsal ring (five examples; Fig. 4.6). The prevalence of these types of modification and the clean breaks indicate that they were the result of anthropogenic and not natural processes. The cutting of shell into fragments was also a common modification, with all Strombus tricornis (377 examples) and Pteriidae (14 examples) represented by fragments (Fig. 4.7). The two examples of Anadara antiquata were both cut fragments (Fig. 4.8), as were the two Conus nussatella (Fig. 4.9). Fragments of Oliva ancillarioides (two examples) and Conus erythraeensis (two examples) were also recorded. Oliva bulbosa was also cut into
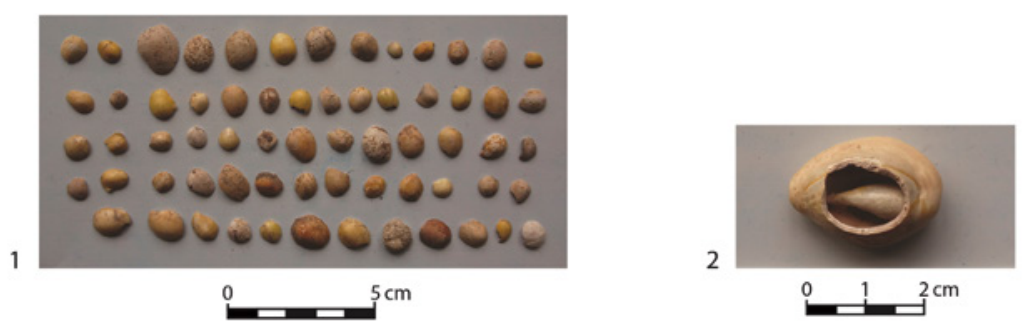


FIGURE 4

Forms of shell modification at Harlaa. (1) Cypraea dorsa (HAR18-B-5). (2) Monetaria annulus with dorsum removed (HAR17-B-22). (3) Marginella monilis with dorsum removed (HAR18-B-11). (4) Cypraea cut in half along the shell (HAR18-B-7). (5) Cypraea cut in half across the shell (HAR16-B-8). (6) Cut off cowry dorsal ring (HAR15-B-5). (7) Cut fragments of Pteriidae sp. (HAR19-E-8). (8) Cut fragments of Anadara antiquata (HAR18-B-14). (9) Cut fragments of Conus nussatella (HAR19-F-6). (10) Oliva bulbosa. Centre with apex removed, cut fragment on right (HAR18-B-1). (11) Oliva ancillarioides with hole in reverse (HAR15-B-5). (12) Engina mendicaria with hole in reverse (HAR18-B-8). (13) Conus erythraeensis with apex removed and surface beneath ground flat (HAR19-F-9)

PHOTOS BY THE AUTHOR 
fragments ( 36 examples; Fig. 4.10), with this process also represented by more complete shells with sections cut from them (six examples) or cut into half (one example). Another Oliva bulbosa modification was the removal of the apex (nine examples), a modification also evident on Oliva ancillarioides (four examples), with one example further modified by having a hole made in it (Fig. 4.11). Deliberate holes were also found made in Engina mendicaria (Fig. 4.12). A dual modified Conus erythraeensis was also recorded, with the apex removed and the surface beneath ground flat (Fig. 4.13). The techniques used to complete these modifications are discussed below.

\subsection{Shell Working Areas}

Before the eleventh century shell was entirely absent at Harlaa, except for a single fragment (Table 4). This is a pattern also manifest in the near total absence of other categories of imported materials prior to this date. Subsequently, the majority of the assemblage, 1748 (73.29\%) worked and unworked marine shells and shell fragments, and four shell beads came from the workshop complex (B) (Table 2). Five phases of occupation and use of the workshop complex were reconstructed between the mid-sixth and early fifteenth centuries (Table 4). Multiple small rooms were recorded that were used by the artisans. These were poorly constructed, usually of a single thickness of ill-fitting stone blocks (Fig. 5). Within or associated with these rooms, ten separate working areas were attested by a sequence of features such as hearths, floors, and stone anvils or working platforms. All the working areas were associated with shell except for two in phase 1, i.e. pre-eleventh century (Table 5). The two best-preserved working areas were from Phase 2 (eleventh to mid-thirteenth centuries), correlating with the highpoint at Harlaa. The features they contained differed, with working area HAR18-B-19 more simply constructed and formed of a hearth, and associated stone anvil or working platform and posthole, the latter possibly for supporting a shelter (Fig. 6). The other working area, HAR15-B-10, was further developed, with a stone anvil or working platform, and a stone pillar carved with a circular cup-mark on top, possibly for beating metalwork on or to hold crucibles or other equipment. These were set into a floor made of schist slabs (Fig. 5). Hearths, walls, and floors were also

TABLE 4 The marine shell species from the Harlaa workshop complex (HAR-B)

\begin{tabular}{|c|c|c|c|c|c|c|}
\hline Shell Species & $\begin{array}{l}\text { Phase } 1 \\
\text { (mid-6th to } \\
\text { 1oth century) }\end{array}$ & $\begin{array}{l}\text { Phase } 2 \\
\text { (11th to mid- } \\
\text { 13th century) }\end{array}$ & $\begin{array}{l}\text { Phase } 3 \\
\text { (late 12th } \\
\text { to late } \\
\text { 13th century) }\end{array}$ & $\begin{array}{l}\text { Phase } 4 \\
\text { (Mid/late } \\
\text { 13th to early } \\
\text { 14th century) }\end{array}$ & $\begin{array}{l}\text { Phase } 5 \\
\text { (late 13th } \\
\text { to early } \\
\text { 15th century) }\end{array}$ & Total \\
\hline Unidentified & 1 & 24 & 5 & 11 & 20 & 61 \\
\hline Cypraea-dorsa & & 267 & 141 & 210 & 464 & 1082 \\
\hline Cypraea - dorsal ring & & & 1 & & 3 & 4 \\
\hline Cypraea & & 65 & 30 & 55 & 105 & 255 \\
\hline Monetaria moneta & & 8 & 8 & 5 & 8 & 29 \\
\hline Monetaria annulus & & 28 & 16 & 5 & 25 & 74 \\
\hline Cypraea erythraeensis & & 1 & & & & 1 \\
\hline Strombus tricornis & & 59 & 22 & 26 & 31 & 138 \\
\hline Oliva bulbosa & & 14 & 13 & 11 & 15 & 53 \\
\hline Oliva ancillarioides & & 1 & 1 & 1 & 4 & 7 \\
\hline Marginella monilis & & 5 & 10 & 3 & 8 & 26 \\
\hline Anadara antiquata & & 2 & & & & 2 \\
\hline Engina mendicaria & & 1 & & & & 1 \\
\hline Conus erythraeensis & & & 1 & 1 & 2 & 4 \\
\hline Pteriidae sp. & & 5 & & 3 & 3 & 11 \\
\hline Total & $\mathbf{1}$ & 480 & 248 & 331 & 688 & 1748 \\
\hline
\end{tabular}




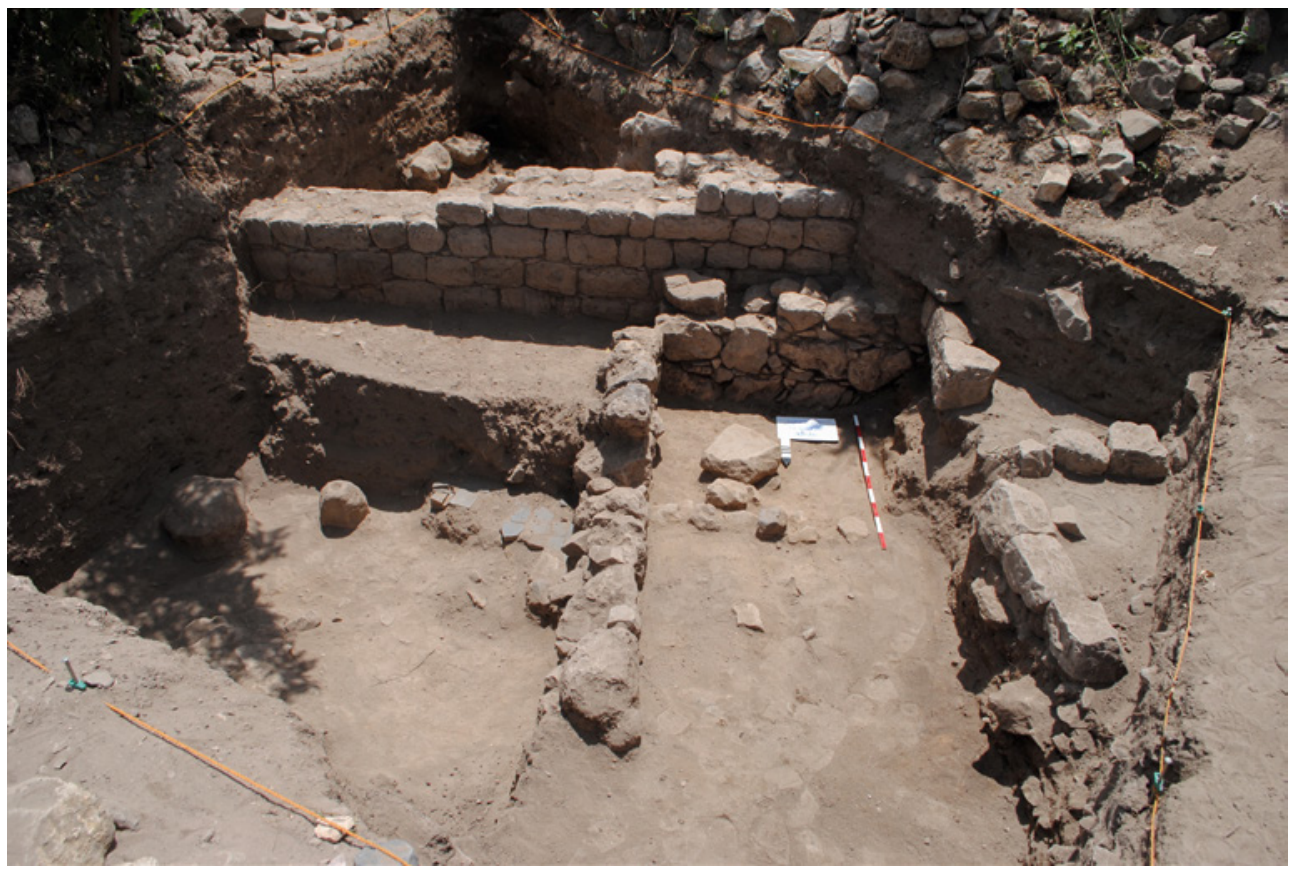

FIGURE 5

Working area with stone anvil or working platform, standing stone with cup mark, and remnants of schist slab floor on left (HAR15-B-10). To the right are three small rooms of the type that were used by artisans in the workshop complex. These are built against a typical 'Harla' wall. PHOTO BY THE AUTHOR

TABLE 5 The ten working areas identified in the workshop complex. Those associated with shell are indicated.

\begin{tabular}{|c|c|c|}
\hline Phase and Date & Context & Features \\
\hline Phase 1 (mid-6th to 1 oth century) & HAR $17-B-15$ & Ash, slag (shell, only fragment in phase) \\
\hline Phase 1 & HAR 17 -B-24 & Hearth \\
\hline Phase 1 & HAR 18-B-24 & Hearth, slag \\
\hline Phase 2 ( 11 th to mid-13 th century) & HAR 15-B-10 & $\begin{array}{l}\text { Charcoal associated with a furnace base, stone anvil, stone floor, } \\
\text { and stone pillar carved with circular cup-mark on top (shell) }\end{array}$ \\
\hline Phase 2 & HAR 1 7-B-9 & Hearth and associated shelter attested by posthole (shell) \\
\hline Phase 2 & HAR 18-B-1 1-12 & Earth floor, agate and quartz bead-making debris (shell) \\
\hline Phase 2 & HAR $18-B-13$ & Hearth, stone anvil or working platform (shell) \\
\hline Phase 2 & HAR 18-B-19 & Hearth, stone anvil or working platform (shell) \\
\hline Phase 3 (late 12 th to late 13 th century) & HAR 16-B-9 & Stone anvil or working platform (shell) \\
\hline Phase 5 (late $13^{\text {th }}$ to early $15^{\text {th }}$ century) & HAR 17 -B-6 & Hearth (shell) \\
\hline
\end{tabular}

recorded in the domestic sites (E, $\mathrm{G})$, and civic building $(\mathrm{F})$, but identifiable working areas and material such as crucibles and slag were entirely absent. These constructions also differed architecturally, the walls being better built of well-cut and fitted dry-stone masonry, larger in size, with plaster floors, and lacking the small structures, stone flag floors, stone anvils, or floors laid onto packing layers of faunal material, as well as the quantities of manufacturing debris found in the workshop complex.

The workshop complex was not a dedicated shellworking workshop. It was a multi-functional manufacturing centre with copper metallurgy and hard stone bead-making also practiced. Metallurgical activities were represented by 216 crucibles and crucible fragments found, many vitrified and some with traces of copper staining. These were only recovered from the workshop complex. It is possible that some of the metal produced was for jewellery casting as indicated by soft stone moulds uncovered by villagers during farming activities but so far unrecorded in the excavations. Discarded roughouts and part-drilled beads indicated the manufacture of both carnelian and quartz beads in facetted hexagonal, rectangular, disc, and short bicone shapes for the former, and flat ellipsoid and long bicone shapes for the latter. Chronologically similar specialized shell workshops are rare, but differ in that shell-working was the only technology represented, 


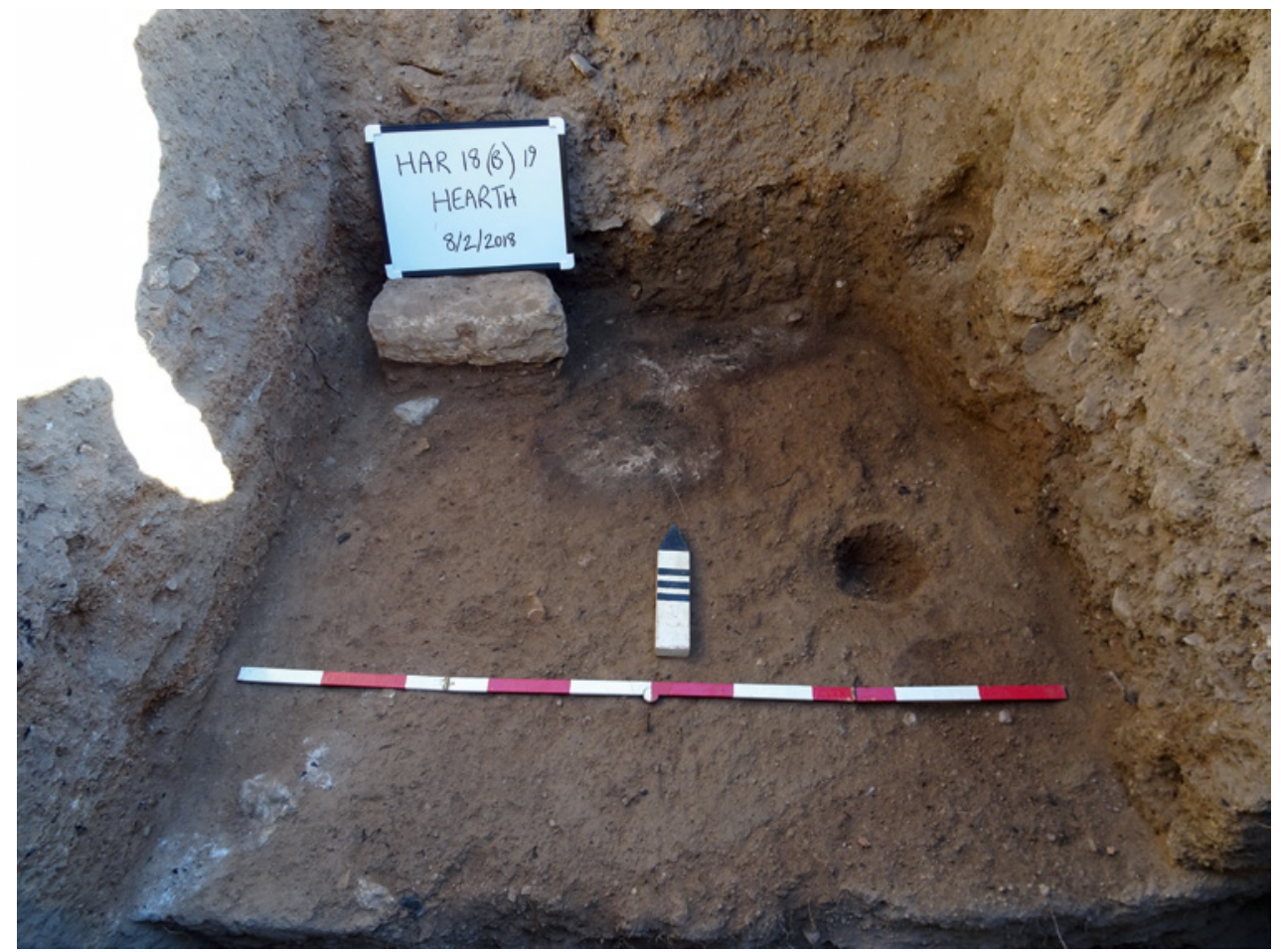

FIGURE 6

Working area with hearth, posthole, possibly for shelter, and stone anvil or working platform (HAR18-B-19)

PHOTO BY THE AUTHOR and shell the sole material found. Building IX in Wadi Tweiba in the Negev (Israel), for example, was an eightroom complex of $15.6 \mathrm{~m} \times 20.5 \mathrm{~m}$ arranged around a central courtyard. It was in operation between the eighth and tenth/eleventh centuries, and appears to have specialised in shell-working for jewellery and inlays, based on the large quantities of shells, both edible and inedible, and also worked shell present (Avner \& Magness 1998: 40).

Cowry processing appears to have been the most significant shell-working activity in the workshop complex as attested by the 1082 (61.90\%) Cypraea dorsa found and 362 whole or part cowries $(20.71 \%)$, being where identifiable almost entirely of the $M$. annulus and M. moneta species, with only a single Cypraea erythraeensis proving the exception. The prevalence of $M$. annulus and M. moneta, as opposed to other cowry species found in the Red Sea (cf. Burgess 1970; Sharabati 1984), mirrors patterns noted across sub-Saharan Africa, where preferences for these species recur (e.g. Haour \& Christie 2019). More specific local requirements may also be indicated by the next most significant groups of shell found, Strombus tricornis $(138$, $7.89 \%)$, and Oliva bulbosa $(53,3.03 \%)$, as well as Marginella monilis. Strombus and $O$. bulbosa were both species used as raw material in Harlaa, with no unmodified Strombus found, though O. bulbosa was also found in complete and modified forms (Table 3). Similar patterns of shell working were maintained across phases 2 to 4 (eleventh to early fourteenth century) suggesting there was no disruption in supply. An increase in phase 5 particularly relating to cowry processing implies a peak prior to the site being abandoned in the early fifteenth century (Table 4).

Shell working was also undertaken in the residential (HAR-E, HAR-G) and civic buildings (HAR-F), confirming it was an activity completed across the site. Differences in the types of shell worked in these sites are apparent with cowry processing occurring at HAR-E but not HAR-F, except negligibly. Manufacturing utilizing Strombus tricornis was also important in both sites with 165 fragments $(32.23 \%)$ recorded in HAR-E and 74 fragments in HAR-F (79.57\%), and thus the working of Strombus would appear to have been particularly important in HAR-E (Table 2). Shell working was not undertaken in the mosque (HAR-A) or the cemeteries (HAR-C and HAR-D), where it would be unexpected (Table 2). The two shells that were found in HAR-A and the two in HAR-C represent accidental losses, rather than meaningful inclusions.

The shell was worked for several purposes: to produce beads from Strombus tricornis; as adornment or possibly stringed as currency when pierced (M. moneta, M. annulus, Oliva ancillarioides, Engina mendicaria, Marginella monilis); for suspension when the apex was removed (Oliva bulbosa, Oliva ancillarioides, Conus erythraeensis); as currency or possibly as ornament applied to other materials when the shell was cut into sections (M. moneta, M. annulus, Oliva ancillarioides, Oliva bulbosa, Conus erythraeensis, Conus nussatella, Anadara antiquata, Pteriidae); and cut sections were also possibly used to produce bangles (Strombus tricornis). 
$3 \cdot 3$

\section{Shell Bead Making}

Shell beads were rare (eight examples, including two from HAR-G) implying they were not an item consumed in Harlaa itself, in contrast to agate and glass beads. Strombus tricornis, or 'three-knobbed conch', appears to have been used for bead manufacture and two recognisable Strombus tricornis beads were found in HAR-G. One of these was cut from the inner lip (Fig. 7.1), and the other from the apex, preserving part of one of the inner whorls in its form (Fig. 7.2 and 7.3). A part finished bead was also recovered from HAR-E, which was likely made from Strombus, but was worked into a long bicone shape precluding identification based on the natural form of the shell. This would have been made by a block or piece of shell of the approximate size being cut out and then carved and filed or ground into shape prior to drilling. The bead had split whilst being drilled and was abandoned (Fig. 7.4). Bow drill use at Harlaa was directly attested by a discarded hand or leg guard made of part of a femur from a large equid that had five holes on the underside (2.2 to $4.3 \mathrm{~mm}$ diameter) caused by the drill spindle (J.M. Kenoyer, pers. comm. 5/7/17; Fig. 7.5). Two bead roughouts were also collected from the surface indicating similar shell working techniques, probably also using Strombus. One, a large bicone, was asymmetrical and had a heavily pitted surface, the other, a short bicone, was more finely finished but also had a surface cavity remaining from the piece of shell used (Fig. 7.6).

It is possible that these bead-making techniques were influenced by or derived from South Asia. Similar large double bicone bead blanks were found at Mantai in northwest Sri Lanka (cf. Francis 2013: 358-359) suggesting
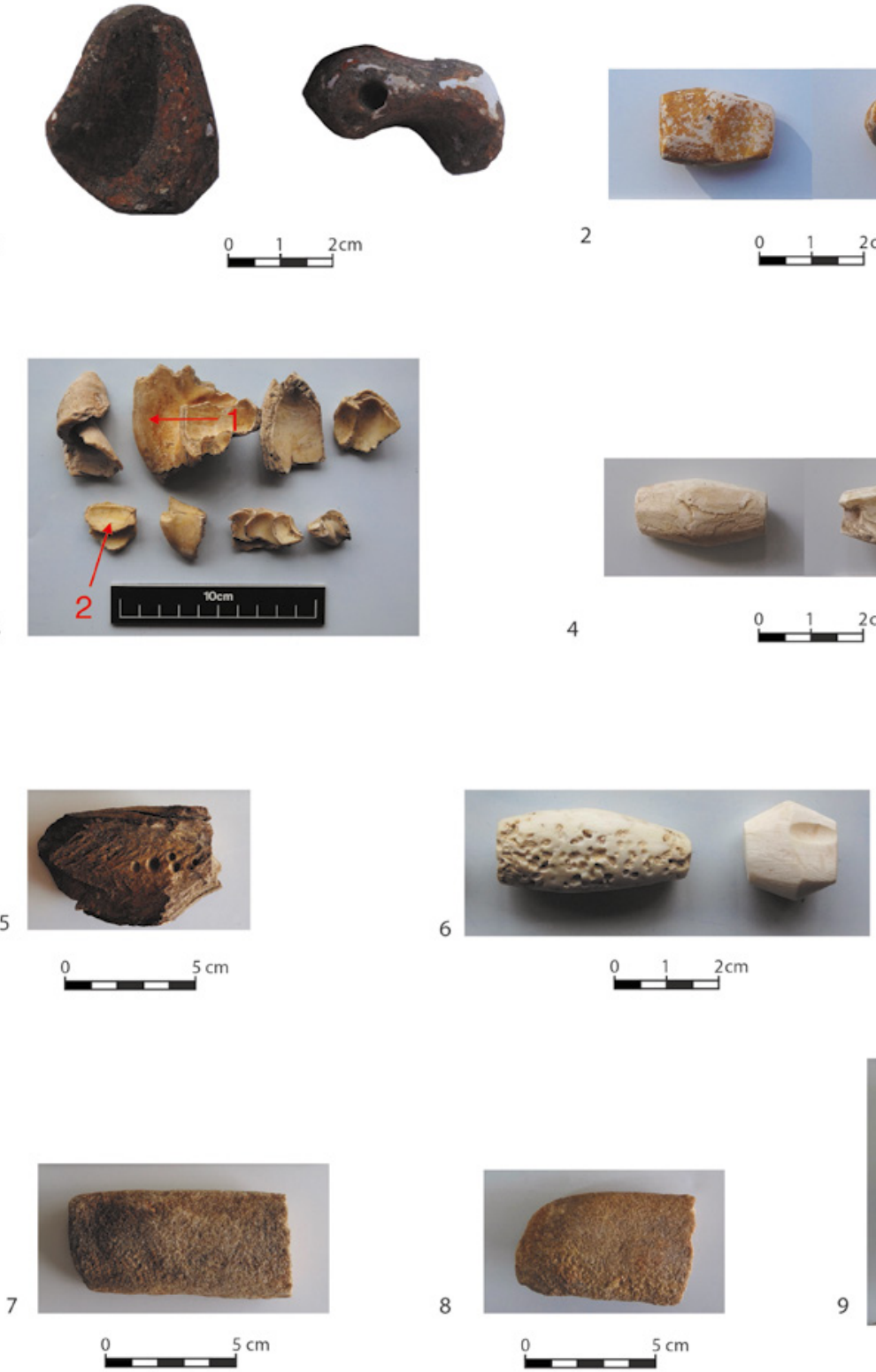

8

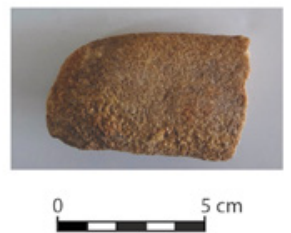

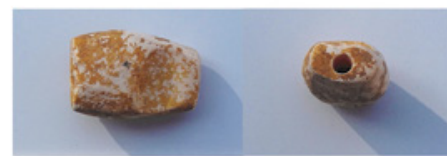
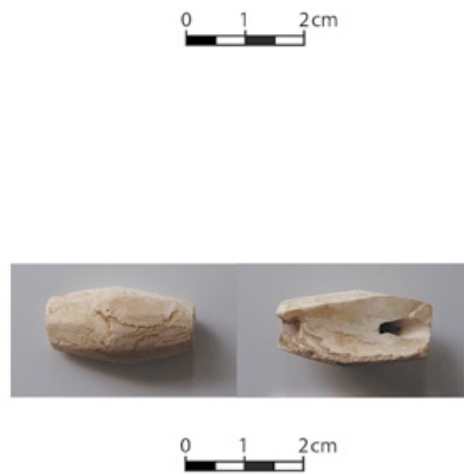

Shell beads and ancillary material from Harlaa. (1) Bead cut from inner lip of Strombus tricornis (HAR2O-G-8). (2) Bead cut from apex whorl of Strombus tricornis (HAR2O-G-14).

(3) Strombus tricornis fragments with arrows indicating comparable parts used to make beads 1 and 2 (HAR15-B-6). (4) Long bicone bead split whilst being drilled (HAR18-E-6). (5) Bone bow drill hand or leg guard (HAR17-B-4). (6) Surface collected bead blanks (HAR15-S/C). (7) Sandstone file (HAR17-B-15). (8) Sandstone file (HAR18-B-24). (9) Gneiss grinding stone (HAR18-B-4) PHOTOS BY THE AUTHOR 
affinities. The shell used and techniques employed at Harlaa also differ from other archaeologically known examples of shell bead making from the wider region such as on the East African coast. At Songo Mnara in southern Tanzania, for example, an aragonite (giant clam shell) bead industry was recorded in contexts dated to the fourteenth to sixteenth centuries with short bicone beads produced in various sizes. These beads appear to be less well finished (cf. Wynne-Jones \& Fleisher 2016: 127, 129), as were the Anadara shell disc and tubular beads manufactured at Shanga in northern Kenya and dated largely to between c. 750-1100 (Horton 1996: 323). Similarly, at Unguja Ukuu (Zanzibar), marine shell disc beads were made from an unspecified shell. These are poorly illustrated but appear to be simple perforated ground discs (Juma 2004: 122, 127). Discs were also the most common beads at Manda (Kenya) with 488 of 502 total from Period 1 (mid-ninth to early eleventh centuries) contexts. Twenty-one cylinder beads were also recovered. Disc bead blanks attested their local manufacture. Only two unspecified cowries are reported (Morrison 1984: 183, 189). Anadara and to a lesser extent, terrestrial snail shell, were also used to manufacture disc beads at Kilwa (Tanzania), and they were most ubiquitous in Period 1 (ninth to late twelfth centuries) contexts. Rare examples of Conus beads were also found dated to Period IIIa (late thirteenth to late fourteenth centuries), and Period v (eighteenth to nineteenth centuries) (Chittick 1974: 473). These differ from the Harlaa Conus beads in having been made from the upper surface of the shell which has been cut away, giving a circular shape with the piercing achieved by the apex being removed (cf. Chittick 1974: 477).

Some natural shells may also have functioned as beads at Harlaa. Both examples of Engina had a hole in the back suggesting this function. A third surface collected Engina had been similarly modified. It would appear that the holes were made by gouging with a pointed tool, rather than hammering or grinding. This is an effective technique on small shells such as Engina, and one example has the characteristic ragged hole left by gouging (cf. Francis 1989: 27) (Fig. 3.9). Identically modified Engina are reported from earlier Ptolemaic and Roman contexts at the Egyptian Red Sea port of Berenike (Then-Obluska 2015: 736). Other 'natural' shells may also have served as beads at Harlaa. At Siraf (Iran), the majority of the Oliva bulbosa shells found in the Great Mosque and adjacent areas, and those from all periods between the fourth and sixteenth centuries, were perforated to be worn as pendants (von den Driesch \& Dockner 2002: 241-242). The removal of the apex on some examples of Oliva bulbosa,
Oliva ancillarioides, and Conus erythraeensis may indicate a similar purpose as beads or pendants at Harlaa. The apex seems to have been removed by grinding, a process recorded on Oliva and Conus in other archaeological contexts (Francis 1989: 28). Grinding involved rubbing the bead on a hard surface to create a hole, often regular, and circular or elliptical in shape (ibid.). This is apparent on an example of Conus where, intentionally or unintentionally, grinding also removed part of the upper surface after the apex was removed (Fig. 4.13). Grinding stones were frequent finds in the workshop complex (66 examples), with lesser quantities found in HAR-E (three examples) and HAR-F (five examples). These await analysis, and though some may have been used for grinding foodstuffs, others appear to have had functions related to manufacturing. These include two rasps or files made of local sandstone, and a small heavily used gneiss grinding stone from the workshop complex (Fig. 7.7-7.9). Besides grinding, it is also possible that the apex in some Oliva bulbosa and Oliva ancillarioides shells were removed by being prised out.

\subsection{Shell Bangle Making}

Shell fragments of three forms suggest that bangles may also have been made at Harlaa, using Strombus tricornis. Two fragments with a rounded edge appear to have been cut from the inside of a circular object (Fig. 8.1 and 8.2). One was from the workshop complex (HAR-B), and the other from a residential building (HAR-E). A single surface collected fragment seems to be from a bangle itself (Fig. 8.3), but no complete bangles were found. A comparable bangle fragment is illustrated by Kervran (2004: 312) from Suhar (Oman) and dated to the ninth to tenth centuries. The third type of fragments suggestive of bangle manufacture were 13 discarded Strombus apex recovered from HAR-B (five examples) and HAR-E (eight examples), along with an additional surface collected example. The interior of the apex indicated where they had been cut so as to remove a circle of material from the outer ring, as well as the internal spiral (Fig. 8.4 and 8.5). The bangle manufacturing techniques are similar to those recorded at Mantai in Sri Lanka in contexts dated to the sixth to twelfth centuries, with the same sawing of the ends of shells to remove circular sections and discarding of broken sawn shell rings (cf. Waddington \& Kenoyer 2013: 386). The difference is in the material, with Turbinella pyrum or 'chank' used at Mantai, a material employed for bangle making in South Asia since prehistory, being found in Mature Indus/ Harappan contexts, from c. 2500-1700 вС (Kenoyer 1984: 54-55; Gaur et al. 2005: 941-942). 

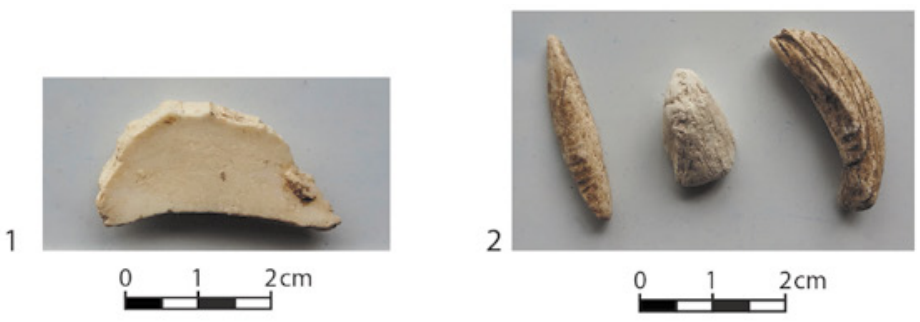

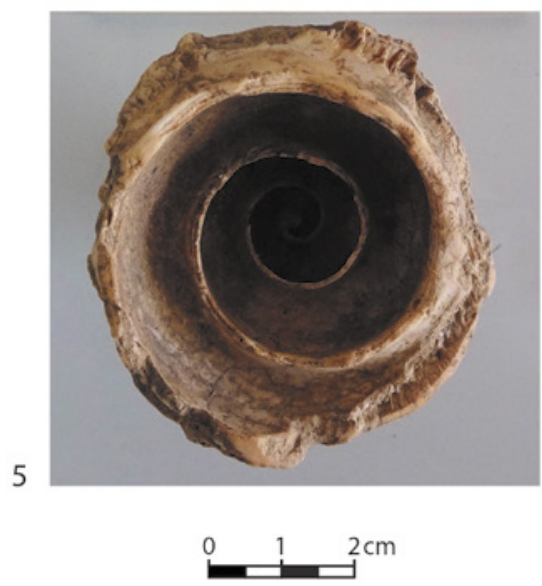

FIGURE 8

Possible Strombus tricornis bangle making debris from Harlaa. (1) Fragment with rounded external cut edge (HAR17-B-16). (2) Three fragments of worked debris. The fragment with the rounded external cut edge is on the right (HAR19-E-20). (3) Cut apex interior on right and bangle ring fragment on left (HAR15-S/C). (4) Cut apex interior (HAR17-B-2). (5) Cut apex interior (HAR18-B-2) PHOTOS BY THE AUTHOR

\section{$3 \cdot 5$}

\section{Shell Cutting}

Shell was also extensively cut and pierced. The removal of the dorsum of the predominantly cowry material is related to a ubiquitous way of processing such shells for stringing and sewing found in sub-Saharan Africa (e.g. Haour \& Christie 2019: 305-306), and in other contexts such as Fustat - Istabl 'Antar in Egypt (Rodziewicz 2012: 266). The technique that appears to have been used to pierce the shells and remove their dorsa at Harlaa is the so-called "popping the cap" (Christie et al. 2019: 493) method. This involves making a small entry hole or perforation and then levering the dorsum off; it is recognizable on the cowry itself by the inward sloping straight edge to the dorsal hole and, sometimes, a notch or more defined keyhole left by the initial perforation (Christie et al. 2019: 497). These are features found on some of the cowries (Fig. 9.1). Additionally, the Cypraea dorsa attest this method, for a further characteristic of 'popping the cap' is the removal of the dorsum as a single piece (ibid: 496-497) (Fig. 9.2). Subsequently, further shell removal 

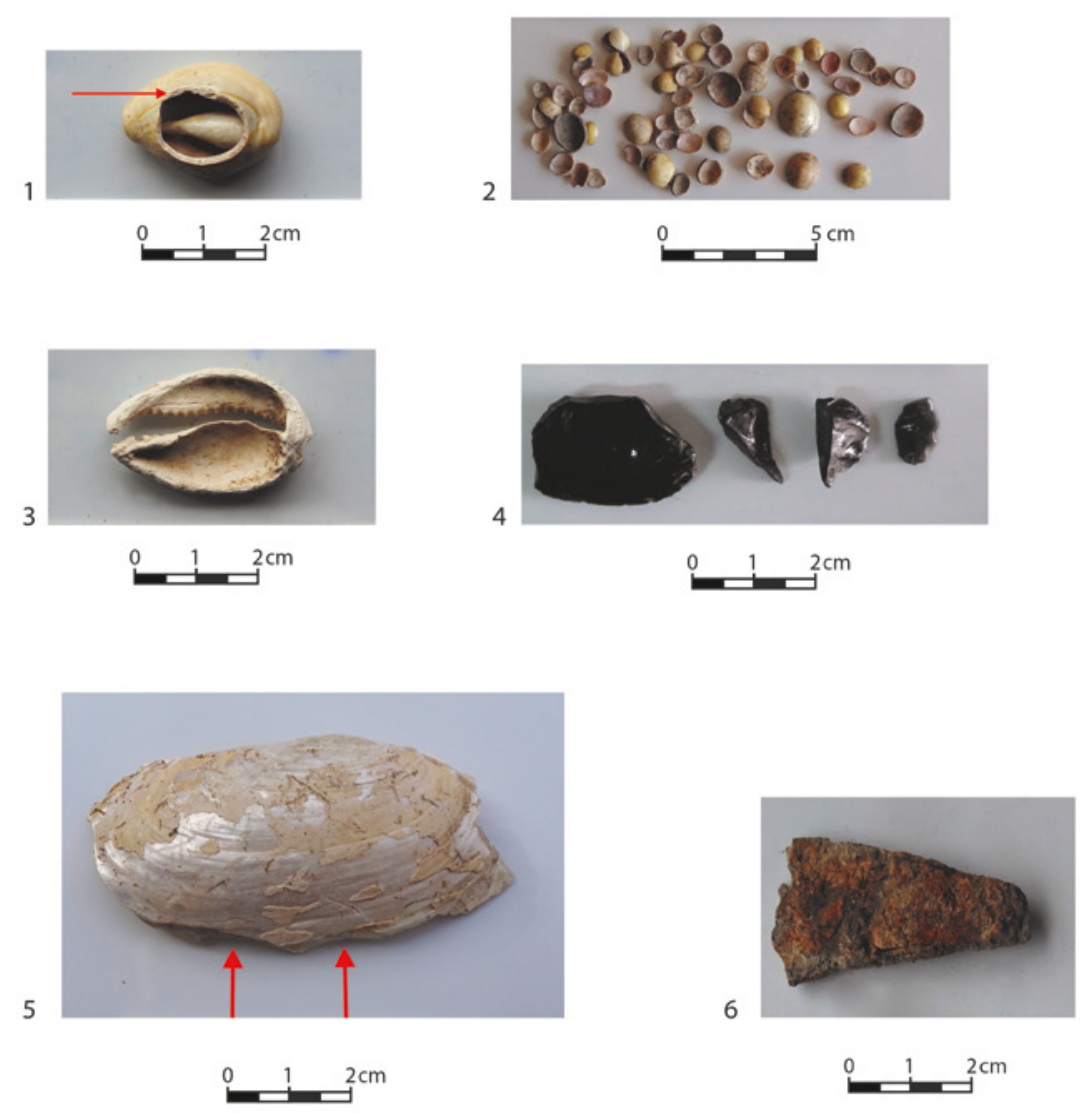


and modification could occur as the five dorsal rings and a single example of a deeply cut Cypraea with the dorsal ring removed indicate (Fig. 4.6 and 9.3).

At Harlaa, Cypraea was possibly cut using obsidian blades. This was a material producing a sharp blade and, as it was readily available, easily renewable. 303 pieces of obsidian, awaiting detailed analysis, but comprising blades, flakes, cores, and debitage (L. Khalidi, pers. comm. 27/2/18), were found at Harlaa. The majority were from the workshop complex (239 pieces), with smaller quantities
FIGURE 9

Cut and pierced shell and ancillary material from Harlaa. (1) Monetaria annulus opened using the 'popping the cap' technique with entry point indicated by arrow (HAR17-B-22).

(2) Cypraea dorsa created by 'popping the cap' (HAR17-B-4). (3) Deeply cut Cypraea after the dorsal ring has been cut off (HAR17-B-14). (4) Examples of obsidian flakes and blades. A fragment used as a 'drill' is second left (HAR18-B-9). (5) Pteriidae sp. with cutmarks indicated by arrows (HAR2O-G-11). (6) Part of iron knife (HAR17-B-4). (7) Part of an iron awl (HAR18-E-5). (8) Saw marks on copper strip indicated with arrows (HAR19-E-28). (9) Strombus tricornis with sawn straight edge (HAR16-B-11). (10) Strombus tricornis fragments with more jagged cut edges (HAR19-F-6) PHOTOS BY THE AUTHOR from HAR-E (36 pieces), HAR-F (25 pieces), and HAR-A (three pieces). These predominantly date to the eleventh to thirteenth centuries, and in the workshop complex two peaks were apparent, with 84 pieces of obsidian from Phase 2 (eleventh to mid-thirteenth centuries) and 70 from Phase 5 (late thirteenth to early fifteenth centuries), the latter correlating with the increase in Cypraea processing previously noted. The obsidian assemblage was not residual, and all categories of obsidian tools were knapped on site. Besides the potential use of obsidian 
blades for cutting Cypraea, and for other aspects of shell (and additional material) working, obsidian flakes also seem to have been used as drills, as suggested by damage to their points (L. Khalidi, pers. comm. 27/2/18) (Fig. 9.4). Possibly, the latter was caused by their use to make the initial perforation before popping the dorsa off the cowry. In Ethiopia, the use of obsidian tools in Islamic contexts has not been investigated. However, obsidian tool use has been extensively studied and is attested from the Early Stone Age as, for example, at the site of Melka Konture (Negash et al. 2006), and continued through until the early twenty-first century (Brandt \& Weedman 1997; Sahle et al. 2012). Obsidian is also abundant in Ethiopia and has been the focus of geochemical provenance analyses (e.g. Negash et al. 2006, 2011; Giménez et al. 2015), including from Porc Epic, a MSA site near Dire Dawa (Negash \& Shackley 2006). The source of the obsidian used at Harlaa, however, is currently unknown, though one might exist in the vicinity of the site (A. Asfawossen, pers. comm. 4/3/19).

It is possible that obsidian was also used to cut other shell such as Oliva Bulbosa or Pteriidae sp. (Fig. 9.5), but it was unlikely to be so effective on thicker shell such as Strombus tricornis. Flint blades were used to cut and saw shell in Upper Palaeolithic and Epi-Palaeolithic contexts in the Levant, but required frequent renewal of the stone tools used (Bar-Yosef Mayer 2014: 92). Iron tools were more probably used at Harlaa. Most iron artifacts were very corroded, but knife blades and awls were identified (Fig. 9.6 and 9.7), and saw marks were found on a strip of copper (Fig. 9.8), indicating their use. Whilst recognizable saw marks were absent on Strombus fragments, the regularity of the cut fragments could also be indicative of sawing the shell (Fig. 9.9). The more jagged cut edges also found may have been caused by either a saw or knife (Fig. 9.10). Microscopic analysis of the shell cut marks will form part of the next phase of research.

Ethiopia, the Red Sea, Egypt, and the Medieval Islamic Marine Shell Trade

\subsection{The Ethiopian Interior}

The quantity of marine shell at Harlaa, c. $120 \mathrm{~km}$ from the Red Sea, implies that it was a trade commodity, both in unmodified and, primarily, modified forms. An extensive and discerning market within Ethiopia is hinted at in the limited Arabic historical sources that exist. Al-Biruni (c. 973-1050), for example, noted that some kinds of cowries (not the smaller ones found at Harlaa), "are the size of eggs. They have backs marked with dots and having slight reddishness. They are strung from the necks of animals, and are used for polishing the gold used for gilding books. They are called minqa $\bar{f}$. A cowrie which has its right speckled side curved to the right is rare. It is considered to be holy and is bought at a high price. People give them as gifts to the kings of Habashah (Ethiopia), on account of the uniqueness of this article" (Said 2007: 117). A key market for the shell workers was probably the Tchercher Mountains to the southwest, where at Sourré-Kabanawa (Fig. 10), c. $40 \mathrm{~km}$ from Harlaa, a group of circular chambered stone tombs were excavated. Two were $\mathrm{C}_{14}$ dated to Cal AD 980-1180 (monument 1) and Cal AD 770-950 and Cal AD 930-1080 (monument 3) (Joussaume 1974: 102), which fall within Phases 1 to 3 in the workshop complex. Harlaa could have been the source of the grave goods recovered including $35 \mathrm{M}$. annulus, some with their dorsa removed, and 40 Oliva bulbosa, some with their apex removed, as well as the copper and silver metalwork and glass beads (cf. Joussaume 1974: Pl. XII-XIV).

Unfortunately, data on marine shell from other relevant sites in Ethiopia is rare due to an absence of research. Cowries were recorded at Nora in thirteenth century contexts (Fauvelle-Aymar et al. 2017: 256) (Fig. 10) but the number found and species are unspecified. Nora was an important Muslim settlement in northeastern Shoa, at the heart of the former sultanate of Ifat. Marine shell is absent in contemporary interior Ethiopian contexts where other imported items are found. No marine shell is reported from the so-called "Shay Culture" (Fauvelle \& Poissonnier 2016: 61) sites such as Tätär Gur (Fig. 10), of tenth to fourteenth century dates, for example. The funerary monuments they are linked with, both tumuli and below ground hypogeum, contained varied grave goods including imported glass beads, of monochrome plain and segmented forms, and multi-colour glass eye-beads, as well as spiral silver rings identical to examples from Tchercher sites such as Sourré-Kabanawa and Raré (ibid: 70). Considering the latter could conceivably be from Harlaa (Insoll forthcoming), the absence of marine shell suggests divergent tastes and differences in sources of supply at the same time as Harlaa was occupied.

\subsection{The Red Sea}

Harlaa was probably supplied with marine shell from one or more of the ports on the Somaliland Red Sea Coast. Pearl diving areas were known as maghāsāt/mughās, and Al-Biruni refers to one at Lujjāh Barbar, "along the straits of Aden on the Ethiopian side" (Said 2007: 124), which might potentially be near Berbera (Fig. 10). Within these entrepots, the general absence of marine shell suggests it was a trade good, and distributed inland from both coasts, east and west, along networks operating from these 


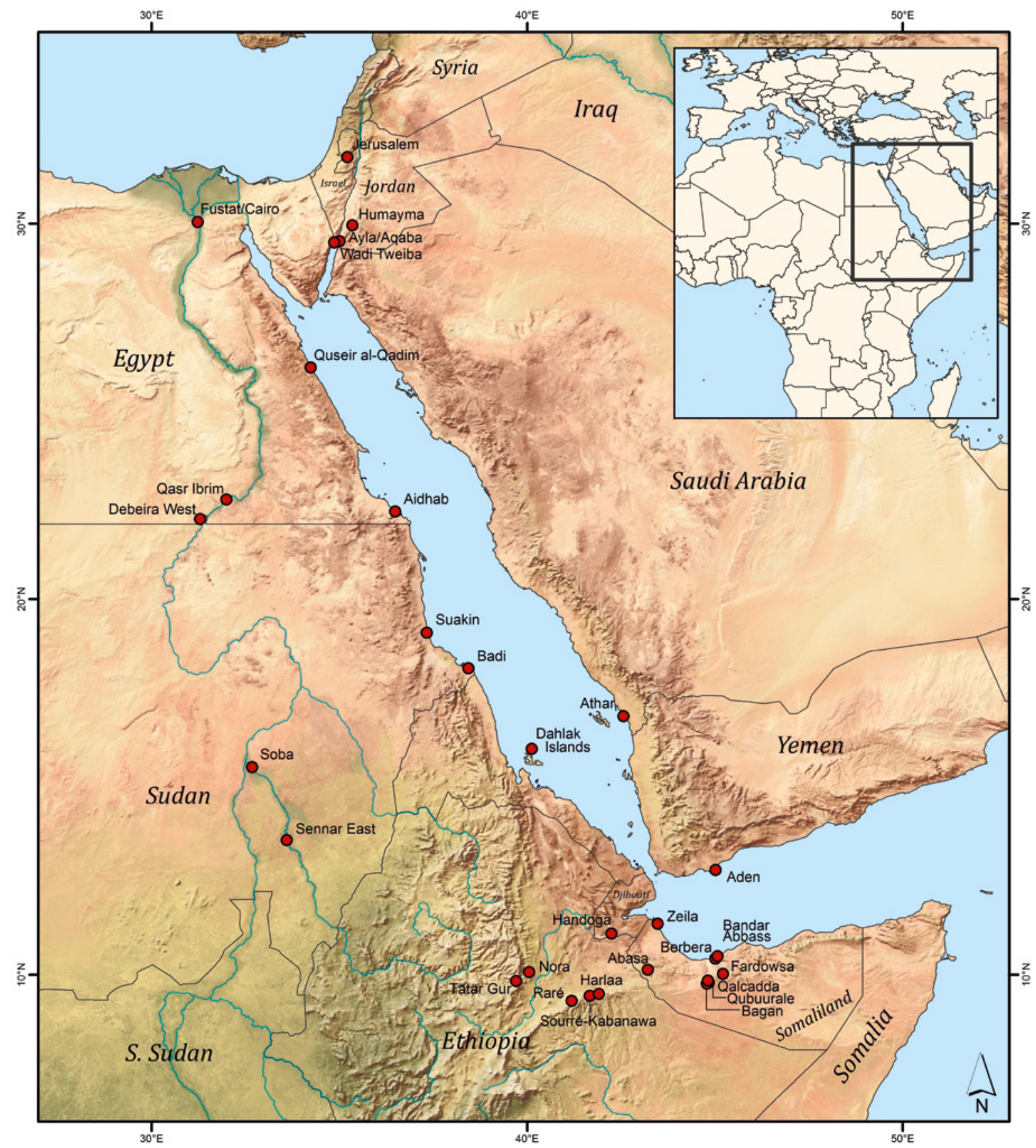

FIGURE 10 The location of sites discussed on the Red Sea coasts and adjacent areas PREPARED BY N. KHALAF

centres, rather than being used or worked in the ports themselves. Perhaps because familiarity with marine shell and proximity of supply rendered it less valuable than in the interior where it was more 'other' and hence of value. At Zeila, where material pre-dating the thirteenth century was lacking, no marine shell was reported (Fauvelle-Aymar et al. 2011; González-Ruibal et al. 2017), with a similar absence at Berbera. The exception was at Bandar Abbass (tenth-twelfth centuries) where "several" perforated M. annulus were found (González-Ruibal et al. 2017: 142), suggesting shell working in the port or within the vicinity.
A trade connection would also explain the "many cowries" (González-Ruibal et al. 2017: 151), otherwise undescribed, recorded at Qalcadda, $85 \mathrm{~km}$ inland from Berbera (Fig. 10), which was considered by the investigators to be an activity area where caravans were unloaded, and exchanges completed.

This pattern of general absence of marine shell is replicated in the settlements (c. twelfth-sixteenth centuries) east of Harlaa on the routes to the Red Sea. Extensive survey of many of these sites in the 1930s found only two fragments of "mother-of-pearl" (Curle 1937:323) (Pteriidae 
sp.), one with a pattern of incised rings, and an unspecified quantity of pierced marine shell disks described as suggestive "of an earlier civilisation" (ibid: 321), indicating they were probably not contemporary. It is possible that other marine shell was unrecorded, but subsequent examination of the Curle Collection (Afl1935) in the British Museum confirmed that no shell had been collected. Where marine shell has been recorded in these sites, only M. annulus or Pteriidae are reported, suggesting particular tastes, and not the eclecticism or quantity at Harlaa. At Bagan (Fig. 10), probably a nomadic campsite with a few permanent structures, "some" (González-Ruibal et al. 2017:155) M. annulus were found, with a further four shells at Qubuurale (ibid: 161), and other examples of M. annulus with their dorsa removed documented at Abasa in a cleared space interpreted as part of the market (Fauvelle-Aymar et al. 2011: 40) (Fig. 10). Whilst at Fardowsa, a fragment of incised Pteriidae was found, as well as the only evidence for shell-working, $M$. annulus "in different stages of piercing" (González-Ruibal et al. 2017: 159), but otherwise undescribed. A similar absence of marine shell exists in the hinterland sites in Djibouti. At Handoga (Fig. 10), shell was completely absent, but other imported goods such as a fragment of a blue glass bracelet, part of a glass flask neck, and two otherwise undescribed Arab coins of eleventh and thirteenth century date are reported (Grau 1976: 8; Gutherz 2013: 31-32). Again, this suggests shell may have passed through as a trade commodity, but was not used or worked at the site which was at the crossroads of several caravan routes, as to Lake Abbe on the Djibouti-Ethiopia border, as well as Zeila (Grau 1976: 5 ).

On the Dahlak Islands (Fig. 10), marine shells were absent, though coral was recorded. It is likely that marine shell is present, but was missed, or went unrecorded in the reconnaissance survey that was completed (cf. Insoll 1997, 2001). The Medieval Sudanese Red Sea ports of Suakin, Aidhab, and Badi (Fig. 10) have also all been archaeologically explored to varying degrees (Insoll 2003: 90-91; Adam 2019: 490-491). Marine shell is not reported from Suakin, where the focus has been on architecture or trade ceramics (e.g. Smith et al. 2012), though unspecified "mollusc shell" is mentioned (Breen et al. 2011: 215). At Badi, shell was listed amongst the materials found in the ad-hoc excavation of a mound (Crowfoot 1911: 543), but is otherwise undescribed. Similarly, shell was also found in subsequent excavations (Kawatoko 1993: 208). More recently, both $M$. annulus and $M$. moneta were recorded as surface finds during a reconnaissance survey of the archipelago Badi is located in (A. Haour, pers. comm. 13/7/20). Abundant celadon wares, other glazed ceramics, and glass vessel fragments were recorded at Aidhab (Paul
1955: 67-68), but shell is not referred to, which must be an omission, as it is described as one of the materials found during later excavations at the site, and recorded in association with black-on-yellow wares of fourteenth century date (Kawatoko 1993: 205). Again, no further detail of the shell is provided.

It is possible that these ports, or an Egyptian source (see below), could also have been the supplier of the limited quantities of marine shell found at medieval sites in Nubia (Fig. 10). Some relevant material exists but, unfortunately, little specific detail on the marine shell is provided. In medieval layers (c. late twelfth to late fifteenth centuries [Adams 1996: 20]) at Qasr Ibrim in Egyptian Nubia, for example, "drilled" cowry shells (unspecified as to quantity or species) were described as "popular as beads", but also their "scarcity" implied they were not locally made (Adams 1996: 98). The latter is an interesting observation as it was likely that they were imported already modified. A single, unspecified, "pierced" cowry was also recovered from Debeira West, north of Wadi Halfa in Sudan (Fig. 10), a site where occupation was dated to between the eighth and eleventh centuries (Shinnie \& Shinnie 1978: 82). At Soba on the Blue Nile, the former capital of the Christian kingdom of Alwa and radiocarbon dated to between the early seventh and early twelfth centuries (Switsur 1991: $35^{\circ}$ ), two pieces of worked, unspecified, oyster shell, a single oyster shell drum bead, a mother-of-pearl incised cut square, and seven unspecified cowries were found (Allason-Jones 1991: 141-142). Further excavations yielded four more pieces of worked mother-of-pearl including a carved pendant cross, as well as a "vessel(?) carved from a large (unspecified) sea shell" (Allason-Jones 1998: 68). Further south data is sparse, but marine shell has been recorded at a site in Sennar East (Fig. 10), also on the Blue Nile. No detail is given but based on the illustration (Nassr 2017: plate 2), a pierced Engina mendicaria, various sized Monetaria moneta and Monetaria annulus with their dorsum removed, and fragments of worked shell including either an M. annulus or M. moneta cut lengthwise into a quarter, and a pierced mother-of-pearl disc were all found during survey at site SEO7, described as the location of a Christian cemetery (Nassr 2017: 149). This marine shell assemblage from the Funj area, rather than the Nubian assemblages, has closest parallels with that from Harlaa.

On the Arabian shore of the Red Sea marine shell has been noted at relevant sites, but has been the focus of even less research than on the African side. At Aden (Fig. 10), Al-Biruni recorded that shells were sold and they were reputedly "brought to Ethiopia from Aden". These were possibly Pteriidae, for he also observed that "rarely does a pearl occur in them" (Said 2007: 124). Unfortunately, shell 
is not referred to in the survey and excavation reports of the Aden area where the focus has predominantly been upon imported ceramics and glass bracelet manufacture (e.g. Lane \& Serjeant 1948; Doe 1963; Lankester Harding 1964; Monod 1978; King \& Tonghini 1996). However, fragmented marine shell can be seen in the background of an image of glass waste/frit from Kawd am-Saylā', and seems to be in the foreground of another image of the remains of a mosque at Kadūmat am-Sha'ībī (cf. King \& Tonghini 1996: plates VII and XXVII) indicating it is present. Further north on the southern Tihama plain in Saudi Arabia was Athar (Fig. 10), an important centre for maritime trade, particularly from the mid-tenth century. Shell is referred to as found in excavations at Athar Area $\mathrm{H}$ (Zarins \& Zahrani 1985: 73), but no further detail is provided. An African connection or presence at Athar was also attested by ceramics recovered, described as burnished black wares, "paddle stamped wares" and geometric decorated black wares with white infill in the incisions, and all given an African provenance (ibid: 81).

The extent to which marine shell was traded from the coastal centres to the interior of the Arabian Peninsula is unknown, but a market appears to have existed. Al-Biruni again provides insight in mentioning that small white cowries called sumūm were used to decorate the hands and feet by Arab women (Said 2007: 117-118), presumably strung as bracelets. At Ayla (Fig. 10), the early Islamic port at Aqaba (Jordan) and a gateway for trade into Jordan and Palestine between the mid-seventh and twelfth centuries, no shell, or even faunal remains, other than worked ivory, are described (e.g. Whitcomb 1988a, 1988b, 1994, 2010). However, the shell working site in Wadi Tweiba was likely supplied with marine shell from Ayla, and identified Red Sea shell has been recorded further north, which also probably transited through Ayla. An example is provided by Humayma, $55 \mathrm{~km}$ northwest of Aqaba. This was the location of one of the compounds lived in by the Abbasid family before they overthrew the Umayyads. Amongst the material found in early Islamic levels were 104 marine shells, with a further 41 recovered from Late Islamic/ Ottoman levels (Perry et al. 2013: 344). All were from the Red Sea with none from the Mediterranean which was $70 \mathrm{~km}$ away, indicating a preference for the former. Food shells such as Tectus dentatus were present, as well as Cypraea turdus and Cypraea pantherina/tigris, but not M. annulus or M. moneta, and Pinctada margaritifera, which was suggested as a food item, secondarily exploited as a source of inlay. Most of the Cypraea had been modified, including cut along the lip, pierced at the anterior end, and having the dorsum pierced or cut off (ibid: 345). Red Sea shells have also been found in various Islamic contexts in Jerusalem (Fig. 10). These included a worked pearl oyster shell (Pinctada margaritifera) dated to the seventh to eighth centuries that was engraved on the interior with a three-ring and dot motif, which is reminiscent of the Somaliland examples. Also reported were species seen at Humayma, Cypraea pantherina/tigris, and Tectus dentatus, as well as giant clam (Tridacna maxima) (Reese 2008: 458-459). The species found thus differ to those recorded in African sites indicating that patterns of marine shell supply from the Red Sea varied, which might reflect availability based on proximity of habitat, or distinct consumer preferences.

\subsection{An Egyptian Connection?}

In Egypt, patterns again vary, with some marine shell species recorded at relevant sites similar to those found further south. At Fustat - Istabl 'Antar (Fig. 10), exact parallels with aspects of the Harlaa assemblage can be seen, as with an Oliva bulbosa with the apex removed and the surface below ground, as well as four Monetaria moneta recovered strung together, whose dorsa had been removed by the 'popping the cap' method (cf. Rodziewicz 2012: 265-266, 473). Additionally, Pinctada margaritifera was being worked as inlay, a species which would be classified as Pteriidae at Harlaa, owing to the size of the fragments found. The Fustat - Istabl 'Antar shell formed part of workshop material but unfortunately the chronology is imprecise with the area burnt in 750 during the reign of the Umayyad caliph Marwan II, and re-used in subsequent Abbasid and Fatimid periods (Rodziewicz 2012: xxxix).

Marine shell has also been recorded at Quseir alQadim on the Red Sea coast of Egypt (Fig. 10). This was an important port in both the Roman and Islamic periods as it was located at the shortest overland route between the Nile Valley and the Red Sea (Whitcomb \& Johnson 1979, 1982: 1; Blue 2002). It also had connections with, or population from, regions further south such as the Sudan, Ethiopia, and perhaps the East African coast, as some of the ceramics suggest, including roulette and incised decorated wares (Whitcomb 1982: 151, 171). The Islamic period (c. thirteenth to fifteenth centuries) shell assemblage comprised 19 species (Reese 1982: 379-380). Most numerous were Nerita sp. with 45 examples found, 28 of which were pierced. Cypraea was represented by 34 examples including various species defined as Cypraea sp. (16 examples), M. moneta (five examples), and 13 C. tigris, 10 of which were found unmodified as a cache inside a room. Of interest is that $89 \%$ of the Cypraea were from the Islamic levels (Reese 1982: 381 ), indicating that demand for these developed in this period and not the Roman one, 
which correlates with the connecting up of West Africa as a potential market, through Muslim-controlled transSaharan trade. Eleven Conus sp. were also recovered with some, as at Harlaa, having their apex removed for stringing, whilst Pinctada margaritifera (12 examples) may have been eaten, or exploited for pearls or mother-of-pearl according to Reese (1982: 381 ).

Quseir was a transit centre for commodities and goods such as marine shell. The extent to which marine shell was consumed in Fatimid and Mamluk Fustat - Istabl 'Antar and Cairo is unknown, but based on the small number of reported finds might be low. It is instead likely that shell was largely traded onwards from Fustat/Cairo itself to supply the huge markets that existed in West Africa, via North Africa and across the Sahara. The documents in the eleventh century Cairo Geniza provide information on shell trade across North Africa. A letter written by a resident of Qayrawān (Tunisia) refers to shell amongst a list of goods relating to a Jewish merchant who had died there (Gil 2003: 279). Another merchant from al-Mahdiyya also in Tunisia is more specific in describing how there was no market for cowry shells there in the winter, but were supplied by merchants coming by sea in the summer (Goitein 1967: 275). Whilst a court document from Fustat dated 19th August 1101 mentions two bales of cowries that were to be delivered to Tripoli in Libya, items which were avidly "sought after in the Mediterranean area, especially in Spain" (Goitein 2008: 224). A wholesaler, Nahray b. Nissīm, whose correspondence from 1045-1096 survived, also dealt in cowry shells amongst many other products (Goitein 1967: 154). Thus, it can be proposed that the cowries and other shell, sourced from the Red Sea and delivered by merchants connected with Fustat/Cairo to various North African centres, could then have been transferred into networks south across the Sahara.

The Arabic historical sources describing medieval West Africa also suggest links between cowries, West Africa, North Africa, and Egypt. Al-Zuhrī, probably writing in the mid-twelfth century, refers to cowries being imported into the country of the Amìma. This is difficult to identify geographically, other than somewhere west or east of Gao, but the importance here is in the trade route used, which was to North Africa, Al-Andalus, and the desert (Levtzion \& Hopkins 2000: 99-100). The use of cowries as currency in Kanīm, a kingdom in the Lake Chad area, is also described by Al-Umari (b. 1301, d. 1349). The source of the cowries is not mentioned, but significantly Al-'Umarī also records that the inhabitants of Kanim had built a lodge for travellers in Fustat/Cairo attesting specific links with that city (Levtzion \& Hopkins 200o: 26o-261). Sijilmāsa in southern Morocco is also named by Al-Umarī as a centre from which merchants left for the Bilad al-Sūdān carrying cowries, as well as salt and copper (ibid: 276 ).

The archaeological distribution of cowries in West Africa has been extensively reviewed by Haour \& Christie (2019) and indicates both how widespread they are, as well as highlighting the possibly erroneous nature of the assumption that the Maldives and the East African coast were the source of supply (ibid: 298). The origin of the marine shell at Harlaa suggests that the M. annulus and M. moneta found in West Africa could have been primarily sourced from the Red Sea at least until the early sixteenth century and the rise in European trade in these shells via Atlantic sea routes around the Cape, as neither shell can be found in the Atlantic coast off West Africa. The Red Sea was both closer, and after it re-opened in the Fatimid period, following the decline of Arabian/Persian Gulf routes and the shift in power from Iraq to Egypt (Tamrat 1972: 44-46), it was fully connected into trade networks traversing North Africa and, ultimately, to the south of the Sahara (e.g. Levtzion \& Hopkins 2000; Insoll 2003). The Red Sea connection with West Africa may also be attested through other aspects of marine shell. At Essouk-Tadmekka in northern Mali, for example, four shell beads were found, two of which are double bicones seemingly produced by the same carving and grinding processes described for Harlaa (cf. Lankton et al. 2017: 170-171). It is not suggested that Harlaa was a source of West African shell beads or cowries. As indicated, it supplied local and regional markets, but the shells beads from Essouk-Tadmekka appear to attest further resonances with Red Sea marine shell, and the techniques used for working it.

\section{$5 \quad$ Conclusions}

The indications that all the marine shell from Harlaa is of Red Sea origin suggests that a hitherto largely unrecognised source of supply existed in the medieval period. This is particularly pertinent for cowry shells which are often ascribed a Maldivian origin (e.g. Hogendorn \& Johnson 1986). Although the importance of the Maldives as a major source of cowries is undisputed (e.g. Christie \& Haour 2018; Haour \& Christie 2019), it can be proposed that greater complexity existed in medieval cowry shell supply, and in marine shell more generally. Ibn Battuta transited parts of the Red Sea (Gibb 1993: 36o-372), but 
it is his description of the Maldives that refers to cowries (e.g. Mackintosh-Smith 2012: 236-237). This 'historicised' Maldivian cowries, and through the reference to their trade far beyond gave credence to the islands as the source, rather than a source. Yet Battuta is not directly to blame, rather it is his interlocutors, who read the full sentence (unfortunately rendered using obsolete and offensive terminology) that "these cowries are used also by the Negroes in their lands; I saw them being sold at Malli (Mali) and Gawgaw (Gao) at the rate of 1,15o for a dinar", as indicating that Maldivian cowries were being sold in these West African kingdoms. Rather, it can be interpreted as merely referring to the use of cowries in West Africa, which could have been sourced from elsewhere, i.e. the Red Sea.

To better understand the medieval Red Sea marine shell trade, subsequent stages of research will involve determining an isotopic profile through oxygen isotope analysis (e.g. Keith et al. 1964; Leng \& Lewis 2014), for the species of marine shell such as Cypraea and Oliva from Harlaa, and for selected examples of known provenance from the Red Sea, Western Indian Ocean, and Arabian/ Persian Gulf. This will both enable the refinement of a replicable archaeologically relevant methodology and provide an isotopic 'fingerprint' for marine shells from these regions. Interesting patterns are emerging and it is apparent that marine shell, often neglected in comparison to glass beads, glass vessels, or glazed ceramics in interpretations of both regional and long-distance trade, has the potential to provide significant information on interactions, cosmopolitanism, and entanglements in the medieval Islamicate world and beyond.

\section{Acknowledgements}

The author is especially grateful to Andreia Salvador, Senior Curator of Marine Gastropoda and Historical Mollusca, Natural History Museum, London, for guidance on the species identifications, Nadia Khalaf for preparing some of the illustrations, and Helen Anderson, British Museum, London, for arranging access to the Curle collection. He is also very grateful to Annalisa Christie, Anne Haour, and Rachel MacLean for commenting on the paper, and to the Authority for Research and Conservation of Cultural Heritage, Addis Ababa, the authorities in Dire Dawa, and the administrators and community in Ganda Biyo for approving the research. The ERC is thanked for funding the project under grant ERC-2015-AdG BM694254.

\section{References}

Adam, A. 2019. New Perspectives on the Archaeology of the Medieval Period in the Red Sea Area of the Sudan. Azania 54, 487-500.

Adams, W.Y. 1996. Qasr Ibrim. The Late Mediaeval Period. London, Egypt Exploration Society.

Allason-Jones, L. 1991. The Finds. In: Welsby, D.A. \& Daniels, C.M. (eds.), Soba. London, British Institute in Eastern Africa, pp. 126-162.

Allason-Jones, L. 1998. The Small Objects. In: Welsby, D.A. (ed.), Soba II. London, British Museum Press, pp. 6o-81.

Avner, U., and Magness, J. 1998. Early Islamic Settlement in the Southern Negev. Bulletin of the American Schools of Oriental Research 310: 39-57.

Bar-Yosef Mayer, D.E. 2014. Temporal Changes in Shell Bead Technologies Based on Levantine Examples. In: Szabó, K., Dupont, C., Dimitrijević, V., Gómez Gastélum, C. \& Serrand, N. (eds.), Archaeomalacology: Shells in the Archaeological Record. BAR S2666. Oxford, Archaeopress, pp. 91-10o.

Blue, L. 2002. Myos Hormos/Quseir al-Qadim. A Roman and Islamic Port on the Red Sea Coast of Egypt. A Maritime Perspective. Proceedings of the Seminar for Arabian Studies 32, 139-150.

Bosch, D.T., Dance, S.P., Moolenbeek, R.G. \& Oliver, P.G. 1995. Seashells of Eastern Arabia. Dubai, Motivate Publishing.

Brandt, S.A. \& Weedman, K. 1997. The Ethnoarchaeology of Hide Working and Flaked Stone Use in Southern Ethiopia. In: Fukui, K., Kurimoto, E. \& Shigeta, M. (eds.), Ethiopia in Broader Perspective. Volume 1. Kyoto, Shokado Book Sellers, pp. $35^{1-361 .}$

Breen, C., Forsythe, W., Smith, L. \& Mallinson, M. 2011. Excavations at the Medieval Red Sea Port of Suakin, Sudan. Azania 46, 205-220.

Burgess, C.M. 1970. The Living Cowries. New York, A.S. Barnes.

Chittick, N. 1974. Kilwa. London, British Institute in Eastern Africa.

Christie, A.C. \& Haour, A. 2018. The 'Lost Caravan' of Ma'den Ijafen Revisited: Re-appraising Its Cargo of Cowries, a Medieval Global Commodity. Journal of African Archaeology $16,125^{-144}$.

Christie, A.C., Grant, A. \& Haour, A. 2019. Cataloguing Cowries: A Standardized Strategy to Record Six Key Species of Cowry Shell from the West African Archaeological Record. African Archaeological Review 36, 479-505.

Crowfoot, J.W. 1911. Some Red Sea Ports in the Anglo-Egyptian Sudan. Geographical Journal 37, 523-550.

Curle, A.T. 1937. The Ruined Towns of Somaliland. Antiquity 11, $315^{-327 .}$ 
Doe, D.B. 1963. Pottery Sites near Aden. Journal of the Royal Asiatic Society 95, 150-162.

Dussubieux, L. 2018. LA-ICP-MS analysis of artefacts from Ethiopia. Unpublished Report. Chicago, Field Museum.

Fauvelle, F.-X. \& Poissonnier, B. 2016. The Shay Culture of Ethiopia (Tenth to Fourteenth Century $\mathrm{AD}$ ): "Pagans" in the Time of Christians and Muslims. African Archaeological Review 33, 61-74.

Fauvelle-Aymar, F.-X., Hirsch, B., Bernard, R. \& Champagne, F. 2011. Le Port de Zeyla et son Arrière-pays au Moyen Âge. In: Fauvelle-Aymar, F.-X. \& Hirsch, B. (eds.), Espaces Musulmans de la Corne de l'Afrique au Moyen Âge. Paris, De Boccard, pp. $27-74$.

Fauvelle-Aymar, F.-X., Hirsch, B. \& Chekroun, A. 2017. Le Sultanat d'Awfāt, sa capitale et la nécropole des Walasma'. Annales Islamologiques 51, 239-295.

Francis, P. 1989. The Manufacture of Beads from Shell. In: Hayes, I.C.F., Ceci, L. \& Bodner, C. (eds.), Proceedings of the 1986 Shell Bead Conference. Rochester, Rochester Museum and Science Center, pp. $25^{-} 35$.

Francis, P. 2013. The Beads. In: Carswell, J., Deraniyagala, S. \& Graham, A. (eds.), Mantai. City by the Sea. Aichwald, Linden Soft Verlag, pp. 349-369.

Gaastra, J. \& Insoll, T. 2020. Animal Economies and Islamic Conversion in Eastern Ethiopia: Zooarchaeological Analyses from Harlaa, Harar and Ganda Harla. Journal of African Archaeology 18, 1-28.

Gaur, A.S., Patankar, S. \& Patankar, V. 2005. Ancient Shell Industry at Bet Dwarka Island. Current Science 89, 941-946.

Gibb, H.A.R. 1993. The Travels of Ibn Battuta. Delhi, Munshiram Manoharlal.

Gil, M. 2003. The Jewish Merchants in the Light of EleventhCentury Geniza Documents. Journal of the Economic and Social History of the Orient 46, 273-319.

Giménez, J., Sánchez, J.A. \& Solano, L. 2015. Identifying the Ethiopian Origin of the Obsidian found in Upper Egypt (Naqada Period) and the most likely Exchange Routes. Journal of Egyptian Archaeology 101, 349-359.

Goitein, S.D. 1967. A Mediterranean Society. Volume 1. Berkeley, University of California Press.

Goitein, S.D. 2008. India Traders of the Middle Ages: Documents from the Cairo Geniza. Leiden, Brill.

González-Ruibal, A., de Torres, J., Franco, M.A., Ali, M.A., Shabelle, A.M., Barrio, C.M. \& Aideed, K.A. 2017. Exploring Long Distance Trade in Somaliland (AD 1000-1900): Preliminary Results from the 2015-2016 Field Seasons. Azania 52, 135-172.

Grau, R. 1976. La Site de Handoga. Fouilles Archéologiques. Pount 16, 4-22.

Gutherz, X. 2013. L’Archéologie à Djibouti. In: Chiré, A.S. (ed.), Djibouti Contemporain. Paris, Karthala, pp. 15-40.
Haour, A. \& Christie, A. 2019. Cowries in the Archaeology of West Africa: The Present Picture. Azania 54, 287-321.

Hogendorn, J. \& Johnson, M. 1986. The Shell Money of the Slave Trade. Cambridge, Cambridge University Press.

Horton, M. 1996. Shanga: The Archaeology of a Muslim Trading Community on the Coast of East Africa. London, British Institute in Eastern Africa.

Horton, M., Boivin, N., Crowther, A., Gaskell, B., Radimilahy, C. \& Wright, H. 2017. East Africa as a Source for Fatimid Rock Crystal Workshops from Kenya to Madagascar. In: Hilgner, A. \& Grieff, S. (eds.), Gemstones in the First Millennium AD. Mainz, Verlag des Römisch Germanischen Zentralmuseums, pp. $103^{-118 .}$

Insoll, T. (ed.). Forthcoming. Becoming Muslim: Archaeology in Harlaa and Harar, Eastern Ethiopia. Leiden, Brill.

Insoll, T. 1997. An Archaeological Reconnaissance made to Dahlak Kebir, the Dahlak Islands, Eritrea: Preliminary Observations. In: Fukui, K., Kurimoto, E. \& Shigeta, M. (eds.), Ethiopia in Broader Perspective: Papers of the 13th International Conference of Ethiopian Studies. Kyoto, Shokado Book Sellers, pp. 382-88.

Insoll, T. 20o1. Dahlak Kebir, Eritrea. From Aksumite to Ottoman. Adumatu 3, 39-5o.

Insoll, T. 2003. The Archaeology of Islam in Sub-Saharan Africa. Cambridge, Cambridge University Press.

Insoll, T., Khalaf, N., MacLean, R., Parsons-Morgan, H., Tait, N., Gaastra, J., Beldados, A., Pryor, A.E. \& Evis, L. In Press. Material Cosmopolitanism: The Entrepot of Harlaa as Islamic Gateway to Eastern Ethiopia. Antiquity.

Insoll, T., Khalaf, N., MacLean, R. \& Zerihun, D. 2017. Archaeological Survey and Excavations, Harlaa, Dire Dawa, Ethiopia January-February 2017. A Preliminary Fieldwork Report. Nyame Akuma 87, 32-38.

Insoll, T., MacLean, R. \& Engda, B. 2016. Archaeological Survey and Test Excavations, Harlaa, Dire Dawa, and Sof, Harari Regional State, Ethiopia. A Preliminary Fieldwork Report. Nyame Akuma 85, 23-32.

Joussaume, R. 1974. Le Mégalithisme en Ethiopie. Monuments Funéraires Protohistoriques du Harar. Paris, Museum Nationale d'Histoire Naturelle.

Juma, A. 2004. Unguja Ukuu on Zanzibar. Uppsala, Department of Archaeology and Ancient History, Uppsala University.

Kawatoko, M. 1993. Preliminary Survey of Aydhab and Badi Sites. Kush 16, 203-225.

Keith, M.C., Anderson, G.M. \& Eichler, R. 1964. Carbon and Oxygen Isotopic Composition of Mollusk Shells from Marine and Fresh-Water Environments. Geochimica et Cosmochimica Acta 28, 1757-1786.

Kenoyer, J.M. 1984. Shell Working Industries of the Indus Civilisation: A Summary. Paléorient 10, 49-63. 
Kervran, M. 2004. Archaeological Research at Suhar 1980-1986. The Journal of Oman Studies 13, 263-381.

Khalaf, N. \& Insoll, T. 2019. Monitoring Islamic Archaeological Landscapes in Ethiopia using Open Source Satellite Imagery. Journal of Field Archaeology 44, 401-419.

King, G. \& Tonghini, C. 1996. A Survey of the Islamic Sites near Aden and in the Abyan District of Yemen. London, School of Oriental and African Studies.

Lane, A. \& Serjeant, R.B. 1948. Pottery and Glass Fragments from the Aden Littoral, with Historical Notes. Journal of the Royal Asiatic Society 2, 108-133.

Lankester Harding, G. 1964. Archaeology in the Aden Protectorates. London, HMSO.

Lankton, J., Nixon, S., Robertshaw, P. \& Dussubieux, L. 2017. Beads. In: Nixon, S. (ed.), Essouk-Tadmekka. An Early Islamic Trans-Saharan Market Town. Leiden, Brill, pp. 16o-173.

Leng, M.J. \& Lewis, J.P. 2014. Oxygen Isotopes in Molluscan Shell: Applications in Environmental Archaeology. Environmental Archaeology 21, 295-306.

Levtzion, N. \& Hopkins, J.F.P. 20oo. Corpus of Early Arabic Sources for West African History. Princeton, Markus Wiener.

Mackintosh-Smith, T. (Trans.) 2012. The Travels of Ibn Battutah. London, The Folio Society.

Magnavita, S. 2015. 1500 Jahre am Mare de Kissi. Frankfurt, Africa Magna Verlag.

Moffett, A.J. \& Hall, S. 2019. Divining Value: Cowries, the Ancestral Realm and the Global in Southern Africa. Cambridge Archaeological Journal 30, 313-326.

Monod, T. 1978. Sur un Site à Bracelets de Verre des environs d'Aden. Raydan 1, 111-125.

Morrison, H.M. 1984. The Beads. In: Chittick, N. (ed.), Manda. London, British Institute in Eastern Africa, pp. 181-189.

Nassr, A.H. 2017. Sennar Capital of Islamic Culture 2017 Project. Preliminary Results of Archaeological Surveys in Sennar East and Sabaloka East. Sudan and Nubia 20, 146-152.

Negash, A. \& Shackley, M.S. 20o6. Geochemical Provenance of Obsidian Artefacts from the MSA site of Porc Epic, Ethiopia. Archaeometry 48, 1-12.

Negash, A., Alene, M. \& Shackley, M.S. 20o6. Source Provenance of Obsidian Artifacts from the Early Stone Age (ESA) Site of Melka Konture, Ethiopia. Journal of Archaeological Science 33, 1647-165o.

Negash, A., Brown, F. \& Nash, B. 2011. Varieties and Sources of Artefactual Obsidian in the Middle Stone Age of the Middle Awash, Ethiopia. Archaeometry 53, 661-673.

Ogundiran, A. 2002. Of Small Things Remembered: Beads, Cowries, and Cultural Translations of the Atlantic Experience in Yorubaland. The International Journal of African Historical Studies $35,427-457$.

Parsons-Morgan, H. Forthcoming. Chinese Ceramic Consumption Practices in East Africa: Past Materialities,
Entanglements, and Identities (8th-17th Centuries AD). PhD Dissertation, University of Exeter, 2021.

Patscher, S. 2011. Conserving the Objects. In: Gronenborn, D. (ed.), Gold, Slaves, and Ivory. Medieval Empires in Northern Nigeria. Mainz, Römisch-Germanischen Zentralmuseums, pp. 89-97.

Pryor, A., Insoll, T., \& Evis, L. 2020. Laser Ablation Strontium Isotope Analysis of Human Remains from Harlaa and Sofi, Eastern Ethiopia, and the implications for Islamisation and Mobility. STAR - Science and Technology of Archaeological Research 6, 113-136.

Paul, A. 1955. Aidhab: A Medieval Red Sea Port. Sudan Notes and Records 36, 64-70.

Perry, M., el-Najjar, M.Y., Finnegan, M., Reese, D.S. \& Ransay, J. 2013. Chapter 10. Human, Animal, and Plant Remains. In: Oleson, J.P. \& Schick, R. (eds.), Humayma Excavation Report, 2. Nabataean Campground and Necropolis, Byzantine Churches, and Early Islamic Domestic Structures. Boston, American Schools of Oriental Research, pp. 321-38o.

Reese, D.S. 1982. Marine Invertebrates. In: Whitcomb, D. \& Johnson, J. Quseir Al-Qadim 1980. Cairo, American Research Center in Egypt, pp. 379-384.

Reese, D.S. 2008. Shells from Jerusalem: Sites B, D, E, J, S and V. In: Prag, K., (ed.), Excavations by K. M. Kenyon in Jerusalem 1961-1967. Volume V. Discoveries in Hellenistic to Ottoman Jerusalem. Oxford, Oxbow Books, pp. 455-461.

Rodziewicz, E. 2012. Bone Carvings from Fustat - Istabl 'Antar. Cairo, Institut Français d'Archéologie Orientale.

Sahle, Y., Negash, A. \& Braun, D.R. 2012. Variability in Ethnographic Hidescraper Use among the Hadiya in Ethiopia: Implications for Reduction Analysis. African Archaeological Review 29, 383-397.

Said, H.M. (Trans.) 2007. Al Beruni. The BookMost Comprehensive in Knowledge on Precious Stones. New Delhi, Adam Publishers.

Sharabati, D. 1981. Saudi Arabian Seashells. London, vNu Books International.

Sharabati, D. 1984. Red Sea Shells. London, KPI.

Shinnie, P.L. \& Shinnie, M. 1978. A Medieval Nubian Town. Debeira West. Warminster, Aris and Phillips.

Smith, L., Mallinson, M., Phillips, J., Adam, A., Said, A., Barnard, H., Breen, C., Breen, G., Britton, D., Forsythe, V., Jensen van Rensburg, J., McErlean, T. \& Porter, S. 2012. Archaeology and the Archaeological and Historical Evidence for the Trade of Suakin, Sudan. In: Dionisius, A., Cooper, J., Trakadas, A. \& Zazzaro, C. (eds.), Navigated Spaces, Connected Places. Oxford, Archaeopress, pp. 173-186.

Spence, M. Forthcoming. Appendix. SRD Analysis of Glass and Quartz Samples. In: Insoll, T. (ed.), Becoming Muslim: Archaeology in Harlaa and Harar, Eastern Ethiopia. Leiden, Brill.

Stenhouse, P. (trans.) 2003. Futuh al-Habasa. Hollywood, Tsehai. 
Switsur, R. 1991. Appendix I. The Radiocarbon Ages from Soba East. In: Welsby, D.A. \& Daniels, C.M. (eds.), Soba. London, British Institute in Eastern Africa, pp. 350-351.

Tamrat, T. 1972. Church and State in Ethiopia 1270-1527. Oxford, Oxford University Press.

Then-Obluska, J. 2015. Cross-cultural Bead Encounters at the Red Sea port site of Berenike, Egypt. Polish Archaeology in the Mediterranean 24, 735-777.

Von den Driesch, A. \& Dockner, A. 2002. Animal Exploitation in Medieval Siraf, Iran, based on the Faunal Remains from the Excavations at the Great Mosque (seasons 1966-1973). Bonner Zoologische Beiträge 50, 227-247.

Waddington, E.J. \& Kenoyer, J.M. 2013. The Shell Bangles. In: Carswell, J., Deraniyagala, S. \& Graham, A. (eds.), Mantai. City by the Sea. Aichwald, Linden Soft Verlag, pp. 385-395.

Whitcomb, D. 1982. Islamic Ceramics. In: Whitcomb, D. \& Johnson, J. Quseir Al-Qadim 1980. Cairo, American Research Center in Egypt, pp. 133-192.

Whitcomb, D. 1988a. A Fatimid Residence at Aqaba, Jordan. Annual of the Department of Antiquities ofJordan 32, 207-224.

Whitcomb, D. 1988b. Aqaba. "Port of Palestine on the China Sea". Amman, Al Kuba Publishers.

Whitcomb, D. 1994. Ayla. Art and Industry in the Islamic Port of Aqaba. Chicago, University of Chicago Press.

Whitcomb, D. 2010. Ayla at the Millennium: Archaeology and History. Annual of the Department of Antiquities of Jordan 54, $167-176$.

Whitcomb, D. \& Johnson, J. 1979. Quseir Al-Qadim 1978. Cairo, American Research Center in Egypt.

Whitcomb, D. \& Johnson, J. 1982. Quseir Al-Qadim 1980. Cairo, American Research Center in Egypt.

Wynne-Jones, S. \& Fleisher, J. 2016. Coins and other Currencies on the Swahili Coast. In: Haselgrove, C. \& Krmnicek, S. (eds.), The Archaeology of Money. Leicester, Leicester University Press, pp. $115^{-136 .}$

Zarins, J. \& Zahrani, A. 1985. Recent Archaeological Investigations in the Southern Tihama Plain. Atlal 9, 65-107.

\section{Taxonomic Citations (in Order Cited)}

MolluscaBase eds. (2020). MolluscaBase. Monetaria annulus (Linnaeus, 1758). Accessed at http://www.molluscabase.org/ aphia.php?p=taxdetails\&id=216875 on 2020-o8-o6.

MolluscaBase eds. (2020). MolluscaBase. Monetaria moneta (Linnaeus, 1758). Accessed at http://www.molluscabase.org/ aphia.php?p=taxdetails\&id=216874 on 2020-o8-o6.

MolluscaBase eds. (2020). MolluscaBase. Cypraea erythraeensis G.B. Sowerby I 1837. Accessed at http://www.molluscabase .org/aphia.php?p=taxdetails\&id=216792 on 2020-o8-o6.

MolluscaBase eds. (2020). MolluscaBase. Strombus tricornis [Lightfoot], 1786. Accessed at http://www.molluscabase.org/ aphia.php? $\mathrm{p}=$ taxdetails\&id=215359 on 2020-o8-o6.

MolluscaBase eds. (2020). MolluscaBase. Oliva bulbosa (Röding, 1798). Accessed at http://www.molluscabase.org/aphia. php? $\mathrm{p}=$ taxdetails\&id=208374 on 2020-o8-o6.

MolluscaBase eds. (2020). MolluscaBase. Oliva ancillarioides Reeve, 1850. Accessed at http://www.molluscabase.org/ aphia.php?p=taxdetails\&id=847769 on 2020-o8-o6.

MolluscaBase eds. (2020). MolluscaBase. Marginella monilis (Linnaeus, 1758). Accessed at http://www.molluscabase.org/ aphia.php?p=taxdetails\&id=208167 on 2020-o8-o6.

MolluscaBase eds. (2020). MolluscaBase. Anadara antiquata (Linnaeus, 1758). Accessed at http://www.molluscabase.org/ aphia.php? $\mathrm{p}=$ taxdetails\&id=207754 on 2020-o8-o6.

MolluscaBase eds. (2020). MolluscaBase. Engina mendicaria (Linnaeus, 1758). Accessed at http://www.molluscabase.org/ aphia.php?p=taxdetails\&id=212164 on $2020-08-06$.

MolluscaBase eds. (2020). MolluscaBase. Conus erythraeensis Reeve, 1843. Accessed at http://www.molluscabase.org/ aphia.php?p=taxdetails\&id=215491 on 2020-o8-o6.

MolluscaBase eds. (2020). MolluscaBase. Conus nussatella Linnaeus, 1758. Accessed at http://www.molluscabase.org/ aphia.php?p=taxdetails\&id=215434 on 2020-o8-o6.

MolluscaBase (2018). Pteriidae Gray, 1847 (1820). Accessed at http://www.molluscabase.org/aphia.php?p=taxdetails\& id $=1775$ on $2020-08-06$. 